\title{
The Morphology and Seedling Structure of the Geo- philous Species of Peperomia, together with some Views on the Origin of Monocotyledons?
}

BY

\author{
ARTHUR W. HILL, M.A. \\ Fellow of King's College, Cambridge, and University Lecturer in Botany.
}

With Plates XXIX and XXX and three Diagrams in the Text.

MONGST the numerous species of the genus Peperomia which are A found in South and Central America, a few peculiar species have been discovered which are more or less geophilous in habit, having either an underground corm or tuber, or a tuberous rhizome. The possession of more or less peltate leaves also appears to be correlated with the tuberous habit. De Candolle ${ }^{2}$ has grouped these species together by means of this character, and they form the first subdivision in his arrangement of the genus. Dahlstedt ${ }^{3}$, in his recent monograph of the South and Central American Piperaceae, follows on the lines of Miquel's arrangement, and places these species in the section Eutildenia of the subgenus Tildenia, Miq. ${ }^{4}$ The first group of this section, which includes eleven species, is distinguished as having 'tuber hypogaeum rhizoma tuberosum,' and nearly all these species, together with some others as yet undescribed, form the subject of this paper.

In the course of my travels in the Andes of Bolivia and Peru from January to March, I903, I found three or four different species of small bulbous Peperomias growing, either on the exposed hillsides or in clefts of the rocks, at about I3,000 feet above sea-level, and it was partly owing to the difficulty of determining the species, and partly to the discovery of

1 Read in part before the Botanical Section of the York Meeting of the British Association, August, 1906.

2 De Candolle, Prod. XVI, i, p. 393.

3 Dahlstedt, Stud. ïber Siid- und Cent.-Amer, Peperomien, Kgl. Svenska Vet. Akad. Handlingar, Bd. xxxiii, No. 2, Stockholm, I900.

4 Miquel, Syst. Pip., p. 69.

[Annals of Botany, Vol. XX. No.LXXX. October, 1906.] 
a large number of seedlings in the moss surrounding some of the plants, that I was led to investigate all the bulbous and tuberous specimens of this genus preserved in our herbaria, in addition to those in my own collection. These peculiar geophilous forms, which are often less than an inch in height, occur in South America, in the Andes of Peru, Bolivia, and Northern Argentina, and in Central America, in the mountains from Guatemala to Mexico.

The South American specimens resemble minute Cyclamen plants in their habit of growth to a very close degree. In all the known species the underground portion is a corm or tuber, which is more or less spherical, but becoming ovoid, or rather irregular in shape, in old plants. There appear to be two types of corm or tuber exhibited by the South American species. In the one case the roots are borne in a median basal tuft on the under side of the corm, in the position of the primary root, and to this type belong $P$. parvifolia, C. DC. (Fig. 27, P1. XXIX), $P$. verruculosa, Dahlst., \&c.; whilst in the other case, of which $P$.peruviana, (Miq.) Dahlst. ${ }^{1}$ (Figs. I and 2, Pl. XXIX), P. macrorhiza, and P. umbilicata, R. and P. ${ }^{1}, \&$ c., appear to be typical, the median primary root is supplanted by lateral adventitious roots arising from the sides of the tuber. The leaves, though they differ in shape and texture, \&c., are always radical, and spring from the upper surface around the growing point or shoot-apex, and there is no trace of an erect stem; in some old bulbs two or three groups of leaves may be seen on the upper surface of the corm, owing to the branching of the originally single stem-apex.

The Central American specimens are distinct from those of South America as regards their general vegetative habit, and they fall into two well-marked groups, in accordance with the morphological character of their underground tuberous portions. In one group-to which $P$. umbilicata, H. B. and K., P. gracillima, Wats, and $P$. pedicellata, Dahlst. (Fig. 32, Pl. XXX), \&c., belong-there is a small smooth, more or less spherical underground tuber, and the roots arise from a spot on the upper surface to one side of the shoot-apex ${ }^{2}$.

In the other group-which includes $P$. mexicana, Miq. (Fig. 42, Pl. XXX), P. macrandra C. DC. (Fig. 46), \&c.-there is an underground tuberous rhizome, which may be either short and stunted or branched and

1 There is some difficulty with regard to Gaudichaud's specimens collected in Peru in about 1834, which have the number 150 and are referred both to $P$. pernviana and $P$. umbilicata (vide Dahlst., 1. c., pp. $3^{\mathrm{I}}$ and 33). M. de Candolle has been good enough to send me a small specimen of Gaud. No. I50 from his herbarium. The roots were found to arise from the top of the tuber after the manner of the Mexican species (cf. P. pedicellata, Fig. 32, Pl. XXX), and in this particular it is quite distinct from either $P$. peruviana, $P$. unbilicata, $\mathrm{R}$. and $\mathrm{P}$., or any other South American species. It thus appears that Gaud. No. I5o is either a new species for South America, affording a link with the Mexican forms, or that some Mexican specimens have been accidentally placed on the Herbarium sheets with Gaudichaud's original specimens from Peru.

${ }^{2}$ Cf. footnote on Gaud. No. 150. 
creeping; in both cases adventitious roots are borne on the rhizome ${ }^{1}$. The arrangement of the leaves agrees with that described for the South American species. Perhaps the most interesting point brought to light by a study of these plants is the structure of their seedlings, together with the mode of germination and development of the mature plant. These features will be described in detail under the headings of the separate species; but, for the sake of clearness, it may be stated here that in all the various species whose seedlings have been found, the structure is modelled on the same plan ${ }^{2}$. The seedlings have all the external characteristics of those of Monocotyledons, for the seed is hypogeal and contains an absorbent organ, whilst a small green leaf protrudes above the soil (Fig. 7, Pl. XXIX). On examination, however, it is found that both cotyledons are present, but that they have become modified to perform different functions, for one remains permanently within the seed and serves to absorb the reserve materials from the perisperm, whilst the other is drawn out of the seed and serves as an assimilating organ (cf. Fig. 8, Pl. XXIX, and Text-figs. 3-5, p. 402) ${ }^{3}$.

As has been mentioned above, the geophilous species from South and Central America appear to be distinct from one another, and after a careful examination of all the available material at Kew and at the British Museum, it seems highly probable that these two widely separated districts are now quite distinct regions, at any rate as far as this particular group of plants is concerned, and that they have no species in common ${ }^{4}$. Thus, so far as our knowledge goes at present, there appears to be a large tract of country, extending from Peru to Guatemala ${ }^{5}$, from which we have no record of any geophilous species with a pseudo-monocotyledonous method of seed-germination; whether forms like $P$. Sprucei, C. DC. ${ }^{6}$, from the borders of Peru and Ecuador, which appear to have a more or less tuberous rhizome and radical leaves, should be included is uncertain; but although no seedlings have been found, the locality ${ }^{7}$ for the species suggests that it is probably not a member of this pseudo-monocotyledonous group.

A great deal of confusion about the various bulbous species and their habits exists in the literature of the subject, and even the recent monograph by Dahlstedt has failed to clear up the matter satisfactorily. According to the different authorities ${ }^{8}, P$. umbilicata, R. and P. ${ }^{9}$, is recorded

1 In $P$. ovato-peltata, C. DC., from Costa Rica, the roots emerge from the upper surface of the tubers.

2 In addition to the material collected in Peru, I have had the good fortune to find seedlings and young plants in various stages of development in the dry mud adhering to the roots of several Mexican specimens in the Herbaria of Kew and of the British Museum.

3 Vide Hill, A. W., Proc. Camb. Phil. Soc., xiii, p. 20, 1905.

4 Vide footnote, p. 2, Gaudichaud, No. I 50.

5 A distance of abont 2,000 miles by land and of about $\mathrm{I}, 500$ miles in a direct line.

6 Seeman's Journ. Bot., I866, iv, p. I33; Prod., XVI, i, p. 394 ; Dahlst., 1. c., p. 4 I.

7 Tarapoto, on a tributary of the Huallaga, NW. Peru, alt. I, $\mathrm{r} 70 \mathrm{ft}$.

8 Miquel, Syst. Pip., p. 70 ; C. DC., Prodromus, XVI, i, p. 393 ; Dahlst., 1. c., p. 3 I.

9 The species was founded by Ruiz and Pavon (vide F1. Peru, p. 30) on a Peruvian specimen. 
not only from Peru and Bolivia, but also from Guatemala and from Mexico. An examination of the original description and figures of the $P$. umbilicata of Ruiz and Pavon ${ }^{1}$ shows that their specimen bore roots from the sides of the tuber; but in the figure of $P$. umbilicata given in Humboldt and Bonpland ${ }^{2}$ the tuber is globose, and the roots all spring from its upper surface, almost at the same spot, which is to one side of the point of insertion of the leaves.

From these figures it is clear that $P$. umbilicata, R. and $P$., and P. umbilicata, H. B. and K., are distinct species, and the present confusion of the two is due to the fact that these differences in the tuber have not been recognized by Miquel, De Candolle, and others, owing perhaps to the general external similarity of these two species. There are several specimens from Mexico in the Herbarium at Kew which agree with $P$. umbilicata, H. B. and K., and $P$. gracillima, Wats., is undoubtedly a very close ally of these forms ${ }^{3}$.

In addition to these, there is yet another species, collected by Pringle ${ }^{4}$ in Mexico, and formerly considered to be a glabrous form of P. Miilleri, C. DC. As in the other cases mentioned, seedlings have been found which show the same monocotyledonous habit, but the mature plant possesses a well-defined creeping and somewhat tuberous rhizome. This plant, which has been named $P$. macrandra, C. DC. ${ }^{5}$, seems from the structure of its fruits and the character of its rhizome to be nearly related to $P$. mexicana, and is a totally distinct plant from the true $P$. Miilleri ${ }^{6}$.

\section{Fruit And Seed Structure.}

Dahlstedt in his monograph has laid particular stress on the fruits as affording reliable specific characters, and, as far as the geophilous species are concerned, I have found that they furnish very valuable evidence, especially when seen in longitudinal section, as to the probable relationship of the different species (Figs. 3, 8, 29, Pl. XXIX ; Figs. $3 \mathrm{I}$ and 4I, Pl. XXX).

Moreover, owing to the retention of the fruit by the germinated seedling, there is no difficulty in the identification of seedlings which may be collected in the field. The details of the fruit-structure will be given when the several species are described, but with regard to the seeds it will be useful to make a few general remarks in this place. Owing to the similarity of the seeds of the species under consideration with those of $P$. pellucida,

1 Ruiz and Pavon, Fl. Peru, i, p. 30, Tab. 45, Fig. $b$.

2 H. B. and K., Nov. Gen. et Spec., i, p. 59, Tab. xv, Fig. I.

3 The specimen from Guatemala included under $P$. umbilicata, R. and P., No. I430, J. D. Smith (vide Dahlst., 1. c., p. $3 \mathrm{I}$ ), is a new and distinct species.

${ }^{4}$ Pringle, No. $4^{6}{ }_{54}$ in Herb. Kew and Herb. Brit. Mus., determined as P. Miulleri (glabrous form) by C. de Candolle.

${ }_{5}$ C. de Candolle, Ann. du Conserv. et Jard, Bot. Genève, i 898, p. 276 .

6 C. DC., Linnaea, xxxvii, p. 366. 
Kunth, which have been described by Johnson ${ }^{1}$, it will not be necessary to do more than point out a few of the most important features of their internal structure. As in that species, the single integument appears to be composed of two cell-layers, which ripen to form a brown investment to the seed ; within the testa the bulk of the seed is composed of the perisperm, the embryo with its endosperm occupying only a very small space at the apex of the seed just under the micropyle (Figs. 3, 8, 29, Pl. XXIX; and Fig. 3I, Pl. XXX). The cells of the perisperm are closely packed with starch, which is entirely absent from the endosperm-tissue in the dormant seed. The outermost layer of the perisperm differs somewhat in the structure of its cell-walls and in the nature of the cell-contents from the rest of this tissue ; with Methylene Blue and Eosin the walls of this layer take on a deeper coloration than those of the inner cells, but with Water Blue they remain unstained, while the walls of the mass of the perisperm stain violet blue. The cell-contents also differ in that some other small bodies besides starch are present, which stain violet with Water Blue and orange yellow with Iodine, and one is reminded in general appearance of the aleurone layer in the endosperm of grasses. Besides starch, some other highly refractive bodies, whose nature is as yet undetermined, are found in the general perisperm-cells. ${ }^{2}$ The structure of the embryo and endosperm, their relations to one another in the dormant seed, and the earliest stages in the germination of the embryo in these geophilous species, appear to agree in all essentials with the account given for $P$. pellucida (vide Text-figs. I and 2, p. 402).

The interesting problem of the relation of the endosperm to the perisperm, in this and other genera with a similar seed structure, is discussed by Johnson ${ }^{3}$. He produces a considerable amount of evidence to show that the food-material stored in the perisperm can only be utilized by the embryo with the aid of the intervening thin sac of endosperm-tissue, and some further support is lent to this view by a somewhat inconclusive paper by Lewis ${ }^{4}$ on the development of the seed of Phytolacca decandra. Sections of the seeds of my own species in an advanced stage of germination show a definite deeply staining layer of compressed and disorganized cells attached to the perisperm and surrounding the cotyledon (Fig. I6, Pl. XXIX; cf. also Text-figs. $3-5$, p. 402). This layer appears to be the remains of the endosperm, through which the reserve materials must have passed from the perisperm to the developing embryo. The sheathing endosperm was also very clearly seen in a young seedling of $P$. umbilicata, H. B. and K. ${ }^{5}$ (Fig. 30, Pl. XXIX).

\footnotetext{
1 Johnson, Bot. Gaz., vol. xxx, p. 7 ; ib., vol. xxxiv, p. 329 ; Campbell, Ann. Bot., vol. xv, p. I I I.

3 Johnson, xxxiv, pp. 334-5.

4 Lewis, Johns Hopkins Univ. Circ., New Ser., I905, No. 5, p. 34, with figures.

5 Vide p. $39^{8}$.
} 
The exact relation of the endosperm to the perisperm has not as yet been determined, but it seems probable that its function may be to produce the ferment (? diastase) by means of which the reserves in the perisperm are presented in a soluble and easily absorbed form to the developing embryo ${ }^{1}$.

It is of interest to notice that the relations of the endosperm both to the perisperm and to the embryo are of the same nature in the case of the normal dicotyledonous embryo of $P$. pellucida,-where both the cotyledons become green,- as they are in the case of the pseudo-monocotyledonous embryo of these geophilous Peperomias, where one of the cotyledons never leaves the seed, and is purely an absorptive organ (cf. Text-figs. I-5, p. 402). This fact, coupled with others, to be mentioned later ${ }^{2}$, such as the occurrence of stomata, tends to show that this unique method of germination is of fairly recent origin in the genus.

\section{South American Species.}

The fruits of the geophilous species from South America present various well-marked external differences as to their general shape, whether sessile or stalked, the length of the stigma, and the appearance of the pericarp, rough or smooth, \&c. ; but when examined in section they appear to fall into two groups, which are distinguished from one another by the character of the pericarp - whether it forms a broad or narrow belt of cells-and by the nature of the glands, which may consist of a group of cells at the bottom of a pit (Figs. I8-20, 29, Pl. XXIX), or of only a single cell in a slight depression (Figs. 3 and 4, Pl. XXIX; Figs. 3I and 4I, Pl. XXX).

It will be more convenient to describe the fruits in detail and the method of germination of the seeds under the heads of their respective species.

\section{P. PERUVIANA.}

P. peruviana ${ }^{3}$, (Miq.) Dahlst. The fruit ${ }^{4}$ is about $\mathrm{I} \cdot 3 \mathrm{~mm}$. in length by $.5 \mathrm{~mm}$. in breadth, containing a seed about $.6 \mathrm{~mm}$. by $47 \mathrm{~mm}$. (Fig. 3 , Pl. XXIX). The fruit-wall, as seen in section, is composed of $3^{-4}$ layers of cells, the two or three inner ones being easily crushed and somewhat tangentially elongated; all the cells of the pericarp apparently contain chlorophyll. The fruit is bounded externally by a layer of curved and tangentially elongated cells with fairly thick brown walls. Interspersed amongst these at more or less regular intervals are smaller isodiametric cells, slightly sunk below the surface in broad shallow pits (Figs. 3 and 4 , P1. XXIX). These latter cells have unthickened walls and peculiar

1 Cf. Johnson, l. c., p. 333 .

2 Vide pp. 403 and 409.

3 This species, which I collected on the damp hillsides above Guaqui at the south end of Lake Titicaca in Bolivia (alt. I3,000 ft.), has been kindly determined for me by Dr. Dahlstedt, to whom I sent my specimens.

${ }^{4}$ Vide Dahlst., 1. c., Fig. 9, Pl. I. 
refringent contents; they are of the nature of gland-cells (vide p. 405), and remind one of the similar glands on the upper surface of the leaves of these plants or of the glands in Limoniastrum monopetalum ${ }^{1}$.

They appear to be of the nature of hydathodes ${ }^{2}$, and no doubt in this species, which was found growing in damp and shady places, they serve for the excretion of the excess of water. The apex of the fruit, or rather the style, is seen in longitudinal section to be mainly composed of a group of reticulately thickened cells.

\section{Germination.}

$P$. peruviana. The earliest stages in the germination of the seeds of this species have not been discovered, but some of the material is sufficiently young to suggest that the commencement of germination agrees with that of $P$. pellucida, described by Johnson ${ }^{3}$. The stigmatic portion of the carpel is pushed aside by the outgrowing radicle, and is sometimes found adhering to the pericarp wall (Text-fig. 3, p. 402); the radicle grows vertically downwards into the soil and anchors itself by root-hairs. The two cotyledons lying face to face within the seed, surrounded by the endosperm, absorb the food material and pass it outwards along their petioles to be redeposited in a small hypocotyledonary swelling, which very early makes its appearance just below the point of union of the two cotyledon stalks with the axis (Fig. 5, Pl. XXIX; Text-figs. I-4, p. 402). From this point onwards the whole course of the germination differs from that of $P$. pellucida, and as far as I am aware from any other dicotyledonous plant. The hypocotyl remains quite short and becomes bulbous, and starch is deposited in its cells (contrast Johnson, Figs. 37 and 39, also Text-figs. I and 3, p. 402, $\mathrm{I}-4$, p. 420). At the same time the petiole of one of the cotyledons, which is also the larger, elongates whilst the lamina is still within the seed, so that it becomes sharply bent after the manner of the seed-leaf of the Onion; this growth continues until the whole of the leaf is pulled out of the seed, and on emerging from the soil it becomes erect and expands into a small green and slightly peltate lamina (Figs. $5^{-8}$ and ${ }_{3} 3$, Pl. XXIX; Text-fig. 3 , p. 402). The lamina of the smaller cotyledon, however, never leaves the seed, and its petiole remains quite short and slender.

Thus we have here a very beautiful example of the differentiation of labour between the two cotyledons, for whilst one serves entirely as an absorbent organ and is hypogeal, the other is epigeal, and though no doubt the latter is able to absorb some reserve material when within the seed, its main function is that of assimilation (cf. Text-fig. 4, p. 402). In these particular seedlings the laminae of the two cotyledons are somewhat

\footnotetext{
1 Wilson, Ann. Bot., iv, p. 243.

2 Haberlandt, Phys. Pflanz.-Anat., ed. ii, p. 4I 7 .

3 Johnson, Bot. Gaz., xxxiv, p. 33 I ; cf. Figs. 34, 36, 37 .
} 
similar in general outline, being more or less oblong, but the absorbent cotyledon has only a single median vascular bundle, whilst the other has in

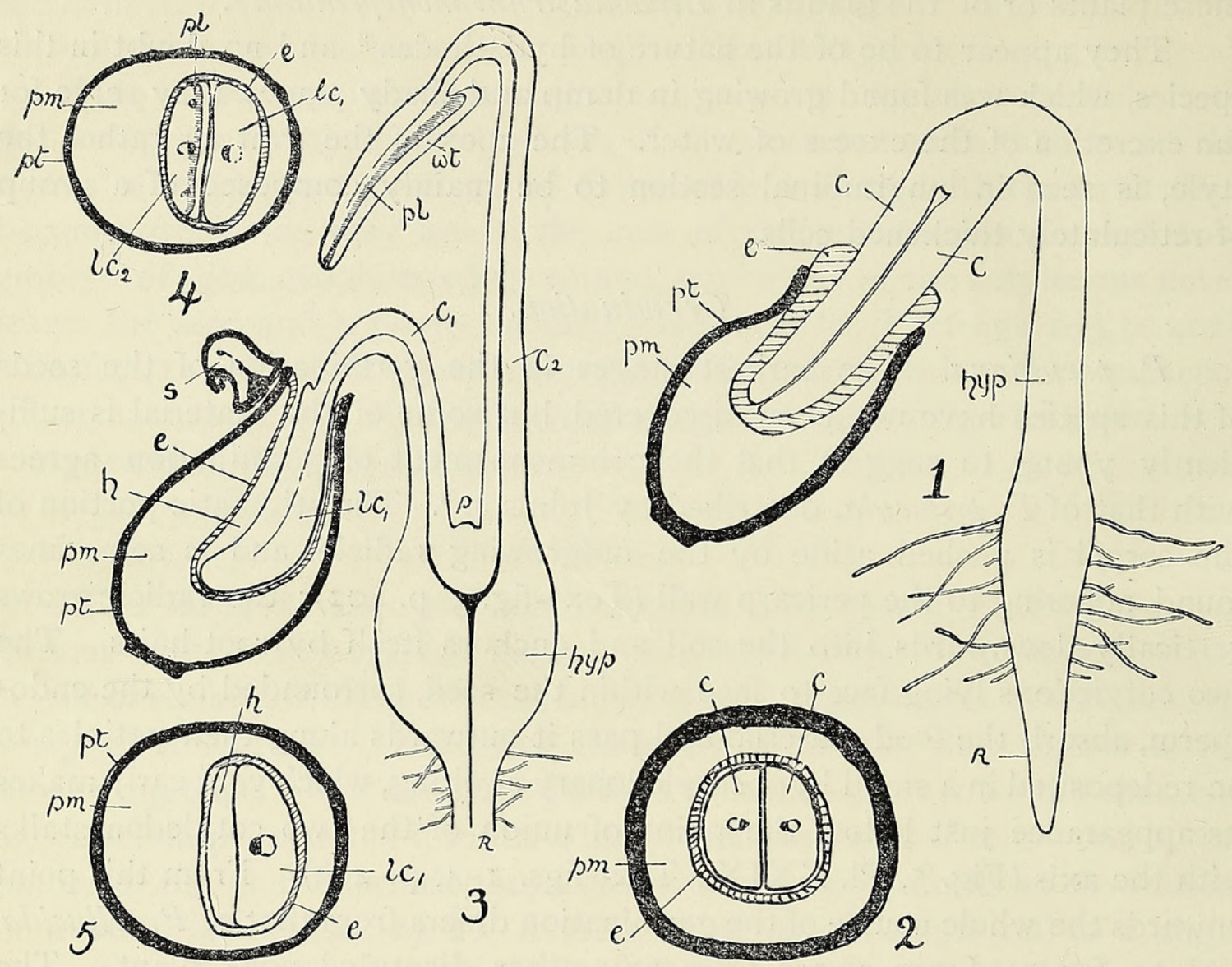

Text-figs. of Peperomia Seedlings.

$p t=$ wall of the seed; $s=$ the remains of the style and micropyle pushed to one side; $p m=$ perisperm $; e=$ endosperm $; c=$ cotyledons $; l c_{1}=$ lamina of absorbent, $l c_{2}=$ lamina of assimilating cotyledon; $h=$ space left in the endosperm by the removal of $c_{2} ; z t=$ water-storing tissue $; p l=$ palisade-tissue $; p=$ plumule hy $p=$ hypocotyl $; R=$ primary root.

Figs. I and 2. $P$. pellucida (after Johnson).

I. A young seedling in median longitudinal section. The two cotyledons are being withdrawn from the endosperm.

2. The seed in transverse section, showing the two similar cotyledons surrounded by the endosperm. The perisperm forms the bulk of the reserve tissue of the seed.

\section{Figs. 3-5. P. peruviana.}

3. A seedling in median longitudinal section, showing the seed with one slightly peltate cotyledon lying in the pouch of the endosperm. The other cotyledon $\left(c_{2}\right)$ has been withdrawn from the endosperm, leaving a hollow space, and will form an assimilating organ. The palisadetissue $(p l)$ is indicated beneath the water-storing tissue $(w t)$ on the upper surface of the lamina. The hypocotyl is becoming swollen to form a corm.

4. A seed in transverse section in an earlier stage of germination than Fig. 3. The laminae of both the cotyledons are still within the seed. The two laminae show dissimilar structure; that of the absorbent cotyledon, $l c_{1}$, remains undifferentiated with a single median vascular bundle, whilst the lamina of the cotyledon which will become the assimilating organ shows a trace of water-storing tissue and of the palisade-layer on its upper surface; also there are three vascular bundles.

5. A seed like that in Fig. 3 in transverse section; the assimilating cotyledon has been withdrawn, leaving a hollow space $(h)$ within the endosperm; the other cotyledon $\left(l c_{1}\right)$ is left in the seed as the absorbent organ (cf. Fig. I6, Pl. XXIX).

addition a lateral curved bundle on each side bending towards the median one near the apex of the lamina (Fig. 8, Pl. XXIX, and Text-fig. $4, l c_{2}$ ). 
In section the epigeal lamina shows water-tissue on the upper surface between the epidermis and palisade-tissue (Text.figs. 3 and 4, p. 402), and stomata and hydathodes on the lower surface.

The lamina of the hypogeal cotyledon, which is also slightly peltate (Fig. 8, Pl. XXIX; Text-fig. 3, p. 402), is seen to be about five to six cells in thickness in a transverse section; it remains, however, undifferentiated as far as its internal tissues are concerned (Fig. I6, Pl. XXIX). In one case two hydathodes were seen near the base, and in all the seedlings examined there were two or three stomata at the apex of the lamina, apparently on the lower side. The stomata in most cases had no starch in their guard-cells ${ }^{1}$, but in two cases, where a stoma was seen near the middle of the lamina, starch-grains were present. It seems quite clear then that we have here to deal with a dicotyledonous embryo, not only on account of the evidence afforded by the majority of the species of this genus, but also from the fact that the two leaves of the young seedling are directly opposite each other and lie with their upper surfaces in contact in the seed (Fig. I3, Pl. XXIX; cf. Text-figs. 2 and 4, p. 402). Moreover their vascular bundles unite directly under the plumule at the same horizontal level to form the central stele of the hypocotyledonary bulb and radicle (Figs. 8 and I4, Pl. XXIX).

The plumule remains inactive throughout the early stages of germination just described, and is seen to consist of a small dome of undifferentiated meristematic cells (Fig. I4). The young fully developed seedling at the end of the first stage of its development thus consists of the two cotyledons, with the rudimentary plumule, a small hypocotyledonary tuber stored with starch, and the primary root (Figs. 7 and 8, Pl. XXIX).

After a time, perhaps at the commencement of the dry season, the aerial cotyledon withers, and eventually leaves a scar, and the young plant, consisting of a small bulb with its primary root, becomes dormant (Fig. 9, Pl. XXIX). The hypogeal cotyledon, however, is not cut off from the bulb, and its lamina still remains within the seed, although it may be dead and withered and all the reserves of the seed exhausted. It is quite common to find the seeds attached to the withered cotyledon of fairly large plants (Figs. I0-I2, P1. XXIX; Fig. 39, Pl. XXX). With the return of favourable conditions the plumule produces the first leaf, and until the plant has attained to some size it never apparently has more than one leaf expanded at a time (Figs. IO-I2, P1. XXIX). Some idea of the age of a little bulb may thus be gathered from the number of leaf-scars or petiole-remains which can be found at the apex of the bulb ${ }^{2}$, though whether only one or several plumular leaves are produced in succession during this second period of activity is unknown (cf. Fig. I2, Pl. XXIX). It is also uncertain how long a period elapses before a bulb is developed which is capable of flowering. The lamina

1 Cf. P. pedicellata, p. 409 .

2 These small bulbs are spherical, and measure about $\mathrm{I} .5$ to $2 \mathrm{~mm}$. in diameter.

E e 
of the first and succeeding plumular leaves differs from that of the aerial cotyledon in being circular in outline and truly peltate, with the insertion of the petiole in the middle of the lamina. It is a somewhat delicate structure, without prominent veins, which becomes thin and membranous when dried (Figs. I0-12, P1. XXIX). In a transverse section there is seen to be a layer of clear, colourless, and sharply defined water-storing tissue on both the upper and lower sides of the lamina, some three cells in thickness, between which comes the narrow belt of assimilating tissue. This latter consists of three rows of cells, the upper one being the palisade-layer of short cells, with two layers of mesophyll cells below, and all containing chlorophyll. Stomata and hydathodes occur in the lower epidermis, and the latter occur sparsely on the upper epidermis, they take the form of a protruding glandular cell with a basal cell below; they are also found on the petioles.

A transverse section of one of these young bulbs shows that the brown colour is due to the old and dead outermost layer of cells, which have been cut off by a layer of hypodermal cork, some four to six cells in breadth. The outermost layer of the bulb is apparently a true epidermis, since the bulb seems to be formed from the hypocotyl. The radicle of the embryo may persist for some time, growing in length and producing lateral branches, though as a rule, shortly after the development of the first plumular leaf, new roots, which ramify extensively, arise from the sides of the little bulb, and soon replace the primary root (Figs. I I and I 5 , Pl. XXIX). The young bulb, at first white externally, soon becomes of a bright brown colour, and at this stage is covered, like the roots, with fairly long epidermal hairs (Fig. Io, P1. XXIX).

Owing to the absence of certain stages in the development of the bulbs it is not clear how the 'hairs' arise, for they do not occur on the hypocotyl of the seedling, though root-hairs are found in abundance on the radicle.

The old bulbs or corms of this species $(P$.peruviana $)$ are about $8 \mathrm{~mm}$. in breadth by $10-\mathrm{I} 2 \mathrm{~mm}$. in length; they are more or less spherical, but with age often become somewhat irregular in shape, and the roots, which are adventitious in origin, are scattered over the base and sides (Figs. I and 2). When the plants were collected in February, they were in full vigour, with a crown of leaves and inflorescences, and the oldest fruits were already ripe; it is possible that the germinating seeds which were found may have been produced this same season ${ }^{1}$.

\section{P. PARVIFOLIA.}

P. parvifolia, C. DC. The fruit in this species differs considerably from that described above; it is about $\mathrm{I} \cdot 4 \mathrm{~mm}$. long by I $\mathrm{mm}$. broad, and contains a seed measuring about $\cdot 8-9 \mathrm{~mm}$. by $.65 \mathrm{~mm}$. (Fig. I 8 , Pl. XXIX).

${ }^{1}$ Cf. Johnson, 1. c., vol. xxxiv, p. 330. 
Externally the fruit appears pitted or corrugated, and has a short dome-like stigmatic cap ${ }^{1}$, which is in great contrast to the nearly smooth fruit of $P$. peruviana with its relatively long stigma (cf. Fig. 3, Pl. XXIX) ${ }^{2}$. In section the fruit-wall is composed of four or five internal layers of parenchymatous cells more or less alike, though the cells of the layer next the integument tend to be tangentially elongated. The outermost or epidermal layer consists of thick-walled square or oblong cells interrupted by frequent pits, at the base of which are the gland-cells (Figs. 18-20)-groups of four cells in the tissue of the pericarp, with peculiar contents, some of which stain blue with Water Blue and appear to be of a mucilaginous nature, whilst others remain unstained and are highly refractive. The stigmatic knob is made up of a group of reticulately thickened sclerous cells. I was unfortunate in not securing any seedling stages of this species, and the ripe fruits which were collected in Bolivia would not germinate on my return home. One germinated seed, however, was discovered in my material which still enclosed the lamina of the absorbent cotyledon. The petiole of this cotyledon, which was broken off from the rest of the seedling, is much longer and stouter than is the case in P.peruviana (Fig. 2I, Pl. XXIX).

On dissecting away the seed, the lamina of the absorbent cotyledon was found to be obovoid or club-shaped, about $.45 \mathrm{~mm}$. in length by $\cdot 35 \mathrm{~mm}$, in breadth, having a circular outline in transverse section. There were apparently no stomata, though this point is somewhat uncertain. The more highly specialized character of the absorbent organ in this species is of considerable interest, for the adult plant is of a much more xerophytic type than $P$. peruviana, and it seems probable that the lamina of the aerial cotyledon is withdrawn in a rudimentary condition from the seed at an early stage in the germination, and thus gives room for the development of the hypogeal cotyledon to join the aroid-like absorbent organ (vide Textfigs. 5 and 6, p. 420), which then completely fills the cavity of the endosperm (cf. Text-figs. 3 and 4 , p. 420 ).

Of bulbs with the first, second, or third, \&c., plumular leaves, several were collected, and from the nature and position of the leaf-scars there can be no doubt that a very similar course of development obtains to that already described (Figs. 23-25). The young bulbs are readily recognized by their size and their whiteness, and by the fact that the roots, which are long and much branched, are produced only from the base (Fig. 23). In a transverse section the epidermis of the bulb is seen to be protected by a thin cuticle, which stains light yellow with Iodine, but there is no formation of cork. The cortical cells, as in $P$. peruviana, are filled with starch, but whilst in that species the starch-grains are more or less rounded and small, they are here considerably larger and ovoid. The plant is a much more pronounced xerophyte than $P$.peruviana (Fig. 27), and this is very well seen

$$
1 \text { Cf. Dahlst., 1. c., P1. I, Fig. } 7 \text {. }
$$

${ }^{2}$ Dahlst., 1. c., Pl. I, Fig. 9. 
in the leaves, whose small ovate, orbicular laminae are rather stout and fleshy and usually slightly concave. In a transverse section of a lamina of a mature leaf there is seen to be a narrow layer of water-storing tissue on the upper surface, consisting of the epidermis and a single row of hypodermal cells, and below this is a double palisade-layer of fairly long cells; the rest of the leaf is composed of spongy mesophyll, the lowest layers of which contain no chlorophyll. Hydathodes, consisting of a protruding gland-cell with a basal cell, are sunk in deep pits, and are distributed chiefly over the lower surface of the lamina, though they occur on the petioles and inflorescence-stalks as well.

The petioles and inflorescence-stalks are short, stiff, and erect; the latter are few flowered and are not much longer than the leaves (Figs. 26 and 27, Pl. XXIX). In old plants the bulbs are generally spherical, about Io $\mathrm{mm}$. long by I $2 \mathrm{~mm}$. across, though in some cases they rẹach a length of I $8 \mathrm{~mm}$. (Fig. 28); in general structure they are typical corms with a single median basal tuft of roots.

This species was found in an exposed position on little damp ledges on a hillside above Copacabana, at the southern end of Lake Titicaca, some I 3,500 feet above sea-level, which no doubt accounts for its pronounced xerophytic characters.

\section{P. Verruculosa SP. NOv., Dahlst., AND other Species.}

Very similar plants, at least as far as their external morphology is concerned, were collected on the exposed hillside of the hill of Sachshuaman, above Cuzco, some I2,000 feet above sea-level.

Although no seedlings were obtained, it is clear that $P$. verruculosa, Dahlst. ${ }^{1}$, belongs to the group under discussion, and the structure of the fruit (Fig. 29, Pl. XXIX) proves it to be a new species allied to P.parvifolia, C. DC. The fruit is about $\mathrm{I} \cdot 4 \mathrm{~mm}$. long by I.I $\mathrm{mm}$. broad, and contains a seed measuring about $\cdot 7 \mathrm{~mm}$. by $.55 \mathrm{~mm}$.

The pittings in the pericarp wall are very much deeper than in $P$. parvifolia, and the fruit has in consequence a much rougher appearance (cf. Fig. I 8). In section the pericarp consists of five rows of cells; the innermost layer, bounding the testa of the seed, is formed of fairly large, clear and tangentially elongated cells, and surrounding these are two layers of small, more or less isodiametric cells. Of the two outermost layers forming the outer wall of the fruit, the external is composed of long radially elongated and often curved cells with thick walls, which are arranged in groups. Between these groups deep pits occur, and four to six cells of the internal layer form a gland at the base of each pit (Fig. 29, g). The

1 This species has been determined by Dr. Dahlstedt from my material, and his description will shortly be published. 
stigmatic knob is small, and is made up mainly of a large group of cells with lignified reticulate thickening. The corms agree in general structure with those of $P$. parvifolia, and the leaves are small, stout, and fleshy as in that species; but in section the band of water-storing tissue is deeper,owing to the greater size of its cells,--and the chlorophyll tissue, with its double palisade-layer, is more restricted than in that species.

A third species, closely allied to the two preceding, was collected near the snow line in a valley (Pacechac) near Urubamba. Ripe fruits were not obtained with this specimen, but in some cases the spikes appear to have produced vegetative buds in place of flowers. The leaves, whilst agreeing externally with those of $P$. parvifolia, are found to differ somewhat when seen in section, for below the narrow two-celled upper layer of waterstoring tissue there is a well-marked triple palisade-layer, and the band of spongy mesophyll on the lower surface is devoid of chlorophyll. Should seedlings ever be found of these two latter species, there is no doubt that they would be pseudo-monocotyledonous in their method of germination.

Other species from this region are $P$. umbilicata, R. and P. , about which there is so much confusion. From the figure of the plant ${ }^{2}$ it appears to be similar in habit to $P$. peruviana, Dahlst., and it is possible that these two species are identical.

P.macrorhiza, Kunth $^{3}$, and P. scutellaefolia, R. and P. ${ }^{4}$, are unrepresented in our British herbaria, but from the figure of the latter species it appears to be closely allied to $P$. umbilicata, and the roots spring from the sides of the relatively large tuber.

\section{Mexican and Central American Species.}

The Mexican and Central American bulbous species appear to form a group distinct from the Peruvian forms, as I have already stated ${ }^{5}$, although there is still considerable confusion about this matter.

\section{P. Umbilicata, H. B. and K.}

One of the commonest forms in our herbaria is the species which has been confused with $P$. umbilicata, R. and P. ${ }^{6}$, but which, as I have shown, is the $P$. umbilicata of Kunth ${ }^{7}$. The examples of this species have all been collected in the mountains of Mexico, in the regions to the north and

1. Mandon's No. II 22, referred to P. umbilicata, R. and P. (C. DC., Prod., XVI, i, p. 393; vide Dahlst., 1. c., p. $3 \mathrm{I}$ ), is without doubt $P$. peruviana, as is also Pentland's specimen collected at I2,880 ft. in Herb. Kew, and described as P. parvifolia in Seeman's Journ. Bot., iii, I866, p. I33. Cf. note on Gaudichaud's No. 150.

${ }^{2}$ Ruiz and Pavon, 1. c., Tab. 45, Fig. $b$.

${ }^{3}$ H. B. and K., Nov. Gen. et Sp., i, p. 72.

* R. and P., Fl. Peruv., i, p. 29, Taf. 44 b.

5 Vide p. 396.

7 H. B. and K., 1. c., p. 59, Taf. xv, Fig. I.

${ }^{6}$ Cf. Dahlst., 1. c., p. 3 I. 
north-west of Mexico city. The ripe fruits are very similar in external appearance to those of $P$. parvifolia, C. DC., but they differ in the character of the pericarp and gland-cells and in the more pronounced stigma. They measure about $1.4 \mathrm{~mm}$. in length by $1.8 \mathrm{~mm}$. in breadth, and the rounded seed is about $.85 \mathrm{~mm}$. by $.8 \mathrm{~mm}$. (Fig. $3^{\mathrm{I}}, \mathrm{Pl}$. XXX) ${ }^{1}$.

The outermost layer of the fruit is composed of thick-walled elongated cells and covered with pits similar to, but rather more shallow than, those in $P$. parvifolia; an important point of difference from this species is that only a single gland-cell occurs at the base of each pit. Below this outer layer the fruit-wall is seen, in a longitudinal section, to be only about three cells in breadth. A single young seedling was found in the Herbarium at Kew which agrees exactly with the seedlings of $P$. peruviana, of the same age, already described (Fig. $3^{\circ}, \mathrm{Pl}$. XXX). The relationship of the endosperm to the cotyledon and perisperm was, however, so well seen in this specimen, on dissecting away the seed, that a brief description is added.

The endosperm fitted like the finger of a glove round the absorbent lamina of the young hypogeal cotyledon, and was attached to the seed-walls all round the apex of the seed, thus shutting off the perisperm from the cotyledon. On treatment with Iodine the contents of the perisperm cells become black-purple, but the endosperm tissue stains brown like the cotyledon and only shows traces of starch, which gives a pinkish purple colour.

From the somewhat club-shaped character of the absorbent cotyledon the seedling of this species seems to occupy an intermediate position between that of the seedlings of $P$. peruviana and $P$. parvifolia.

In their later stages of development, the seedlings of $P$. umbilicata, H. B. and $K$., differ in an important and interesting manner from those of the South American species, and most, if not all of the other species belonging to the Central American and Mexican bulbous group show the same peculiarities. As a fairly complete series of the stages of germination and the development of the young bulbous plant of a Guatemalan species ( $P$. pedicellata, Dahlst.) has been found, a description of these will suffice for the whole group.

\section{P. PEDiCELlata.}

In $P$. pedicellata, Dahlst. ${ }^{2}$, the fruits are borne on long pedicels, which are not quite equal to them in length (vide Fig. 32, Pl. XXX). The fruit, including the stigma, is about $\mathrm{I} \cdot \mathrm{I} 5 \mathrm{~mm}$. long by $\cdot 35 \mathrm{~mm}$. broad, and is linearobovate in shape, the stigma being $.35 \mathrm{~mm}$. in length; the seed measures about $\cdot 7 \mathrm{~mm}$. by $\cdot 3 \mathrm{~mm}$. The fruit-wall is seen, in sections, to be of the same type as the pericarp in $P$. penviviana, Dahlst., having the outermost layer

1 The figure given by Dahlstedt of the fruit of P. umbilicata, R. and P., P1. I, Fig. 8, appears to have been made from a Mexican specimen.

${ }^{2}$ Dahlst., l. c., p. 35, Pl. I, Fig. I3; T. D. Smith, Sta. Rosa, alt. 3,000 feet, No. 3829 ; O. Salvin, Volcan de Fuego, 6,400 feet, Guatemala. 
composed of tangentially elongated cells with single gland-cells interspersed (Fig. 4I, Pl. XXX).

In the youngest seedling stages discovered, the aerial cotyledon is fully expanded; its lamina is rotund-cordate to ovate more or less acute, about $3.5 \mathrm{~mm}$. long and $2.5 \mathrm{~mm}$. broad, trinerved and very slightly peltate, the insertion of the petiole being almost at the base. The hypogeal cotyledon, as in the other cases, remains embedded in the seed, and the petioles of the two cotyledons spring from a small, slightly swollen hypocotyl, which is prolonged into the short primary root or radicle (Fig. 33, Pl. XXX). On dissecting away the fruit and seed the included, absorbent lamina is found to be oblong in shape, .6 to $.7 \mathrm{~mm}$. in length, obtuse and slightly concave, with a single median vascular bundle (Fig. 34). Near the middle, and apparently on the lower side of this cotyledon, a single stoma was found in one case, with starch in the guard-cells; whilst in another case three stomata were found at the apex of the cotyledon, but there was no indication of starch. These latter stomata may perhaps be of the nature of water-stomata. Slightly older seedlings show further stages in the development of the tuber; the primary root, which at first is in a straight line with the hypocotyl and plumular dome, becomes laterally displaced, owing to the growth of the tuber taking place mainly on one side. At about the same time a lateral root is given off from the base of the primary root, and this at first grows upwards, but then bending over, keeps a more or less horizontal course at about the level of the top of the tuber (Figs. 33 and 35).

The unilateral development of the tuber continues, with the result that the point of insertion of the primary root is gradually carried round until finally the root or tuft of young roots comes to spring from what is now the upper surface of the bulb (Figs. 35-38). The point of origin of the roots thus lies to one side of the shoot-apex on the physiologically upper surface of the tuber, so that these points are separated from one another by only a small intervening space, which represents one of the sides of the hypocotyl of the young seedling. The small spherical bulb or tuber is a true corm, as in the South American species, but, owing to this curious asymmetrical development, it has assumed the appearance of a root tuber, such as one finds in Ramunculus ficaria. When the primary root has been brought round to the upper surface of the tuber in the manner just described, it becomes replaced by numerous lateral roots, which spring from its base; these then grow out all round over the top of the bulb in the horizontal direction, and pass on either side of the shoot with its leaves. The roots are thickly covered with root-hairs and do not branch very freely, but they all spring very definitely from one spot (Figs. $3^{8}$ and 39). In an old tuber an occasional root can be found arising a little away from this spot. 
Longitudinal sections through young and old tubers show this peculiar unilateral development in a very striking manner. The course of the stele in the hypocotyl of the seedling is at first vertical (cf. Fig. 34, Pl. XXX); this then becomes curved, being pushed aside by the stronger development of cortical tissue on one side of the hypocotyl, until it forms a semicircular loop at the upper end of the young tuber, uniting the now contiguous points of egress of stem and root. The main mass of the tuber is situated below this stelar loop, and consists of parenchymatous tissue stored with starch; the tuber is bounded by a cuticle, but there is no development of any corky tissue (Fig. 40, Pl. XXX).

The tuber never seems to attain to any large size; the largest seen are about $5 \mathrm{~mm}$. in transverse diameter by $3 \mathrm{~mm}$. in height, of a yellow colour, and often have a wrinkled skin. Since we have no precise information as to the nature of the habitats of the species which possess this type of tuber, or of the particular conditions under which they grow, it may not be very profitable to speculate on the possible reasons for this peculiar adaptation. The roots running horizontally above the tuber show that their object is to be close to the surface of the soil, and this would suggest that the need of oxygen may have stimulated them to grow in this manner. This view is strengthened on recognizing the definitely apogeotropic nature of the first lateral root of the young seedling (Figs. 33 and 34).

The leaf petioles in $P$. pedicellata, Dahlst., are some 6 to $7 \mathrm{~cm}$. long, and bear cordate-peltate acute laminae, some 2.5 to $3 \mathrm{~cm}$. long by about $2 \mathrm{~cm}$. broad (Fig. 32, Pl. XXX). Owing to the small size of the tuber, it seems probable that the plants are able to grow actively with the help of their leaves and roots during the damp season, and are not dependent on the store of nutriment in their tubers. During the dry season or on the incidence of an unfavourable time this organ may be of great value to the plant, both in preserving its life and in affording a supply of nutriment for the resumption of active growth on the recurrence of favourable conditions.

The texture of the lamina in the dry specimen is membranous and thin, like that of $P$. peruviana, and is in marked contrast to the small thick lamina of $P$. parvifolia and its allied species. This character suggests that the habitat of the species is damp and shaded, at least during the vegetative period, and the position of the roots is also suggestive of a wet situation ${ }^{1}$.

\section{Other Bulbous Species.}

P. umbilicata, H. B. and $\mathrm{K} .{ }^{2}$, is a much larger and stouter plant than $P$. pedicellata, having fairly large orbicular and medianly peltate leaves, which are firm in texture and possess clearly marked veins. The tuber is

1 It is of interest to notice that $P$. peruviana, which bears its horizontally running roots on the sides of its tubers, also grows in damp and shady places.

2 H. B. and K., 1. c., i, p. 59, Taf. xv, Fig. I. 
described by Kunth as being about the size of a pea, but in some examples with old tubers it is considerably larger.

The closely allied $P$. gracillima, Wats. ${ }^{1}$ is very similar to the last species, only rather more slender, and as there are no ripe fruits it is not possible to be certain whether it is merely a varietal form or a true species ; both plants are said to grow in damp places among rocks, and a greater or lesser degree of exposure would of course cause a considerable difference in the appearance of plants belonging to the same species. It seems probable that $P$. claytonioides, Kunth ${ }^{2}$ from Guatemala, $P$. ovato-peltata ${ }^{3}, \mathrm{C}$. DC. from Costa Rica, and $P$. pinulana ${ }^{4}, C$. DC. from Guatemala may also belong to this same group, but it is impossible to be certain of this from the literature of the subject.

\section{Rhizomatous Forms. P. MEXiCANA.}

Turning now to the other group of the Mexican species referred to at the commencement of the paper ${ }^{5}$, there are two or three forms with a more or less creeping rhizome whose seedlings have been found to be of the same character as those already described. The best known and most certainly defined species in this group is $P$. mexicana, Miq. ${ }^{6}$, which has also been described and figured under the name of $P$. Galeottiana by Hooker ${ }^{7}$. As the character of the underground portion is not well shown in this figure a fresh illustration is given of this species (Fig. 42, P1. XXX).

$P$. mexicana occurs in the Cordillera of Vera Cruz; it possesses a short tuberous rhizome bearing lateral protuberances, which give it the appearance of a compound tuber when viewed from below. Towards the stem-apex it narrows and bears a tuft of radical leaves and the roots appear to arise from this upper narrower portion. The fruit (cf. Dahlst., 1. c., Fig. I2) is distinct from that of $P$. pedicellata since it is sessile and has a long style with a peltate stigmatic head (Fig. 43). The pericarp, however, is smooth as in $P$. pedicellata and there are only single gland-cells in the shallow pits. The fruit measures about $\cdot 9 \mathrm{~mm}$. long, exclusive of the style-which is about $.6 \mathrm{~mm}$.- by about $\cdot 3-\cdot 4 \mathrm{~mm}$. broad, and it is linear-oblong in shape.

1 Watson, Proc. Amer. Acad., xxii, p. 448, No. 585, Palmer, Jalisco, Mexico, in deep recesses of overhanging rocks.

${ }^{2}$ C. DC., Prod., XVI, i, p. 400 ; Dahlst., 1. c., p. 33. M. de Candolle kindly informs me that in this species the roots emerge from the upper part of the tuber.

3 C. DC., Seeman's Journ. Bot., iv, p. I33, I866 ; ib., Prod., XVI, i, p. 324 ; Dahlst., 1. c., p. 34 .

${ }^{4}$ C. DC., Engl., Jahrb., x, p. 289, 'radice reniformia Tuberosa.' Hab. Pinula prope Xalapa alt. $\mathbf{I}, 800 \mathrm{~m}$. This species is considered to be a variety of $P$. claytonioides.

5 Cf. p. 396.

${ }^{6}$ Miq., Syst, Pip., p. 75 ; Nov. Act. Nat. Cur., p. 12, Taf. vi, 1846; Dahlst., 1. c., p. 34, Pl. I, Fig. I 2.

? Hooker, Icones, vol. iv, Tab. $32 \%$. 
Two seedlings were found amongst the roots of the specimen at Kew, and they agree closely with those of $P$. pedicellata already described. The hypogeal cotyledon is somewhat obovate in shape, and slightly concave, whilst the aerial cotyledon is broadly oblong, acute, trinerved, and only peltate at the base. The primary root grows vertically downwards, but at its base a lateral secondary root is very soon developed which grows upwards, and then bending out horizontally continues to grow in this direction (Figs. 44 and 45 ).

It is unfortunate that the whole course of the development of the plant cannot be followed in this species, but it seems probable that the roots may get carried round to the upper surface as in the other Mexican species, and that the rhizome is produced by the continued growth of the stem-apex.

The leaves of the mature plant have fairly long and slender petioles, their laminae are ovate-lanceolate in outline, trinerved, and scarcely peltate ; in texture they are thin and membranous when dried, and the plants evidently grow in damp and shady places (v. Fig. 42).

Another plant, which should probably be placed here, is Hartweg's specimen ${ }^{1}$ from Aguas Calientes in North Mexico: it has a short stout tuberous rhizome with roots arising from all over the surface. The upper part is marked by closely crowded leaf-scars. The ripe fruits with their large pericarps differ considerably from those of other species, but no seedlings have as yet been found.

\section{P. MACRANDRA, C. DC.}

The only other species of this group, of which we have knowledge of the seedlings, is a well-marked species, which appears to have been confused with P. Miilleri, C. DC. ${ }^{2}$, but which is now known as P. macrandra, C. DC. The plants in question were collected by Pringle ${ }^{3}$ in Mexico, at an elevation of 8,500 feet; they are of particular interest in having a very definite creeping rhizome, which is somewhat tuberous in character, and bears roots on the lower side (Fig. 46, Pl. XXX).

The leaves are all radical and spring from the apex of the rhizome, and the whole plant is glabrous. The petioles have broad bases, and large semicircular or reniform leaf-scars are left on the rhizome by the fallen leaves ${ }^{4}$. There is no overlapping of petiole bases as in P. Miilleri, C. DC. The rhizome is about $4 \mathrm{~mm}$. in diameter. The leaf lamina is broadly ovate-lanceolate, acute, peltate with five principal veins, the insertion of the

1 Benth., Pl. Hartweg, p. 293. This plant, No. I62I, is referred to P. monticola, Miq., which does not appear to be a correct determination; a plant collected by Schaffner (No. 108) at San Louis Potosi seems to be identical with No. I62 I (Herb. Kew).

2 Linnaea, xxxvii, p. $3^{66-7}$; Dahlst., 1. c., p. 37.

${ }^{3}$ Pringle, No. ${ }^{6} 5_{44}$, on the wet ledges of the Sierra de San Felipe, Oaxaca, Mexico. Herb. Kew and Herb. Brit. Mus. Labelled P. Mülleri, C. DC., glabrous form.

${ }^{4}$ Since writing this paper I have paid a visit to Geneva and find that M. de Candolle has described this plant as a new species in the Ann. du Conserv. et Jard. Bot. Genève, 1898, p. $27^{6}$. 
petiole being below the middle, about a quarter of the length of the lamina from its lower edge. The fruit is about $.8 \mathrm{~mm}$. in length, almost sessile, and the stigma is almost equal in length to the fruit (Fig. 47).

Two young seedlings were found adhering to the dry specimen, and they are of exactly the same character as those already described in this paper (Fig. 48). Unfortunately only the cotyledonary stages of the young plants were found, and no light is thrown by these on the formation and development of the rhizome, but it seems likely, on the analogy of the other species of the group, that it must be hypocotyledonary in origin. There seems to be a fairly close relationship between this species and $P$. mexicana, not only in the fruit structure, but also as regards the general external morphology.

Of other species from Mexico P. Mülleri, C. DC. and P. Bourgeani ${ }^{1}$, C. DC. have well developed creeping rhizomes, which are covered by the persistent petiole bases; the plants are hairy, and the cordate leaves are slightly peltate; there is, however, no evidence to show whether or no these species belong to this pseudo-monocotyledonous group.

\section{AnATomy.}

With regard to the anatomical structure of the seedlings, there is but little to be said. The only seedlings available for section cutting were those of $P$. peruviana. A transverse section near the base of the cotyledons shows a small median collateral vascular bundle in each cotyledon, that of the aerial cotyledon being the larger, and as one passes down below the point of union of the two cotyledons, in a series of sections, these two bundles are seen gradually to approach one another. The plumule is rudimentary at this stage, being represented only by a small knob of meristematic tissue; thus the only vascular bundles in the young seedling are the two cotyledonary traces. The phloem consists of a group of delicate thin walled elements, and the xylem is composed of a few small spiral vessels. The transition from stem to root appears to take place by means of the splitting of the phloem and rearrangement of the xylem; but, owing to the state of the material, it was very difficult to follow all the changes. As far as could be seen, there did not appear to be any preparatory division of the phloem of the cotyledonary traces whilst still within the petioles ${ }^{2}$. The root shows a simple diarch structure, with only two or three lignified elements forming the xylem-plate (Fig. $17, \mathrm{Pl}$. XXIX) ${ }^{3}$.

1 Linnaea, xxxvii, p. 370 ; Dahlst., 1. c., p. 44, Fig. 16, Pl. I. Both these species have been collected at Orizaba in Mexico. P. Bourgeaui is represented at Kew by Bourgeau, No. 323o, and P. Mülleri by Müller, No. 653 , and a Guatemalan specimen, No. 3826 , of J. Donnell Smith (cf. Dahlst., 1. c., pp. 37 and 44). They all agree very closely together, and there seems to be little doubt that these two species are identical.

${ }^{2}$ Cf. Hill, T. G., Ann. Bot., xx, p. I 70.

${ }^{3}$ Cf. Hill, T. G., 1. c., Pl. X, Fig. 6. 


\section{General Considerations.}

Several points of general interest and of somewhat wide bearing are suggested by the facts which have been detailed in the foregoing pages; but, in the first place, it will be best to summarize the evidence which has been obtained from the study of these geophilous Peperomias. The internal structure of the seed has been found to agree with that which obtains in normal species of the genus, and there is little doubt that the early history of the embryo follows the usual course. In its germination, however, it reveals some striking aberrations from the dicotyledonous type common to the majority of the species, for the scedling is, in appearance, monocotyledonous.

Although the embryo is dicotyledonous in structure, the monocotyledonous character of the seedling is due to the fact that the two cotyledons show a division of labour; for whereas one serves as an absorbent organ, the other is mainly, if not entirely, an assimilating organ. That we have really to deal with two cotyledons in these species seems to me to be proved by the following considerations.

In the first place, the initial pair of leaves of the young seedling are always opposite to one another (cf. Fig. I3, Pl. XXIX), having their upper surfaces in contact within the seed, and the seedlings appear to agree very closely, in the youngest stages, with the dicotyledonous embryo of $P$.pellucida. Secondly, the vascular bundles, which are similar in structure in both the petioles, fuse together below the plumule at the same horizontal level, and appear to take equal shares in the composition of the central stele of the hypocotyl and root (cf. Fig. 14, Pl. XXIX). In the third place, it must be borne in mind that these geophilous species form a very small subgroup of a large genus whose various species, with these exceptions, show, as far as we know, a perfectly normal dicotyledonous embryo; and we have every reason for supposing that the structure of the seedlings is homologous throughout the genus.

Certain features which are noticeable during germination suggest that the monocotyledonous tendency is a fairly recent acquisition in the genus, and is, moreover, directly correlated with the adoption and development of the bulbous habit ${ }^{1}$. Amongst such features, the sharp bend or hook exhibited by the petioles of both of the cotyledonary leaves may be mentioned (cf. Figs. 5, 6, and $\mathrm{I}_{3}, \mathrm{Pl}$. XXIX). This no doubt is a reminiscence of the time when both cotyledons were epigeal. Now only one cotyledon becomes aerial and bears the pressure of the soil on its sharply bent petiole (Fig. 6). In a normal species such as $P$. pellucida ${ }^{2}$, it is seen that

1 Cf. Darwin, C., The power of movements in Plants, p. 97.

${ }^{2}$ Cf. Text-fig. I, p. 402, and Text-figs. I and 2, p. 420, also v. Johnson, Bot. Gaz., xxxiv, Figs. $3 \mathrm{I}, 37,39, \mathrm{Pl}$. X. 
the two cotyledons remain within the seed for some time absorbing the reserve materials, and are not withdrawn until the reserves are exhausted. It is interesting to notice that these aberrant forms afford a close parallel in this respect, for at first in $P$. peruviana, and perhaps in all the other species, both cotyledons serve for a short time as absorbent organs. With the withdrawal of the aerial cotyledon, a cavity is left within the endosperm, which in $P$. peruviana is never entirely obliterated by the further growth of the absorbent cotyledon; in fact the lamina of this organ retains its dorsiventral character within the seed, and, moreover, is seen to be slightly peltate, thus preserving the character of a foliage leaf (Fig. I6, Pl. XXIX; Text-figs. $3-5$, p. 402). P. peruviana thus exhibits somewhat imperfect or intermediate modifications of its seedling structure from the dicotyledonous type, which suggest that such modifications have been only comparatively recently initiated in this species.

In $P$. parvifolia, however, the modification of the seedling structure seems to have proceeded still further towards the monocotyledonous ideal, for in this species the absorbent cotyledon is obovoid, or club-shaped, and has lost its dorsi-ventral character, so that apparently it fills the cavity of the endosperm (Fig. 22, P1. XXIX, and Text-figs. 5 and 6, p. 420) ${ }^{1}$. The greater degree of specialization exhibited by the seedlings of this species is of considerable interest, for the adult plants of $P$. parvifolia, $P$. vermculosa, and my own undetermined specimen from Pacechac ${ }^{2}$, are very strongly xerophytic, and form a closely related group, which must be considered to have advanced further in their adaptation to the bulbous habit than any other of the geophilous species.

The absorbent cotyledon in P. umbilicata, H. B. and $\mathrm{K} .{ }^{3}$, also appears to be more or less spherical (Fig. 30, Pl. XXIX), and it is somewhat significant to notice that this species exhibits characters more markedly xerophytic than do its allies both in the structure of its leaves and of its fruits ${ }^{4}$.

Further traces of the once normally dicotyledonous character of the seedlings, particularly in reference to the reduction of one of the aerial cotyledons to function wholly as an absorbent organ, are afforded by the occurrence of stomata and hydathodes ${ }^{5}$ on their laminae. Stomata have been found in nearly all the absorbent cotyledons which have been examined; they are quite normal in appearance, and starch has been found in the guard-cells in one or two cases, where they were situated near the middle of the lamina; more commonly the stomata occurred at the apices

1 Stomata were not distinguished, but only a single specimen was available for examination; cf. p. 405 .

2 Vide p. 407.

3 No. 63 I, Bourgeau, Santa Fé, Vallé de Mexico, in Herb. Kew.

4 For the other Mexican and Central American bulbous species, vide p. 408.

5 Hydathodes were found in one case out of about five seedlings of $P$. perwviana examined; they were situated near the base of the lamina on the lower surface. 
of these little leaves, two or three together, but in such cases no starch was seen and they thus appear to be rather of the nature of water stomata. In either case it is difficult to see that they can be of any value to the absorbent cotyledon, since its lamina is never withdrawn from the seed.

Finally, in the persistence of the primary root for some time after the formation of the bulb (cf. Figs. 7-IO, Pl. XXIX, \&c.), we have additional evidence of the essentially dicotyledonous character of these seedlings.

\section{The Geophilous Habit.}

The species of Peperomia under discussion are confined to the high mountain regions of the Andes and of Central America, and in their adult forms they show different biological adaptations, which no doubt represent their response to the peculiar xerophytic conditions of their several localities. Adaptation to new conditions must have appeared first in the adult structure of the plant, and the tendency to bulb production must be due to the shortening of internodes; but, it seems clear, from the consideration of analogous cases, that changes, leading eventually to the evolution of acaulescent forms, may take place without any appreciable effect on the structure of the seedling ${ }^{1}$. With further advances towards geophily, however, involving, e.g. the formation of a swollen stem-structure in definite response to xerophytic conditions, the initiation of the necessary structural modifications of the adult would begin to be thrown back more and more into the early stages of the plant's development, until finally the structure of the embryo itself would become involved.

It is obviously of paramount importance to a plant if the conditions are severe-such as, e.g., the occurrence of a long dry season - that a bulb shall be formed by the young seedling as quickly as possible, and in the most economical way ${ }^{2}$. We must suppose such changes to have been brought about in the seedling-which I am considering to be dicotyledonous-in response to the xerophytic conditions of the situation. The almost universal method in which this problem of bulb-formation has been solved is by the rapid transference of the reserves of the seed into the tissues of the hypocotyl, which in its turn has become adapted to receive them. The urgency of making an underground storage as rapidly as possible has no doubt been the exciting cause for a division of labour between the cotyledons. In the geophilous Peperomias, one cotyledon has been found to be capable of performing efficiently the functions of absorption ${ }^{3}$, whilst its fellow has acquired the equally important function of

1 Cf. Primrose, Koh1 Rabi, Plantago, \&c., \&c.

2 The special biological advantages accruing from the adoption of the geophilous habit are clearly stated by Miss Sargant in her paper, Ann. Bot., xvii, 1903, pp. 79 and 80.

${ }^{3}$ Cf. Cyclamen, where only one cotyledon is developed which absorbs the reserves in the seed, whilst the other remains rudimentary. 
supplementing, during the favourable season, the reserves from the seed by means of carbon assimilation.

To adaptations of this nature may be ascribed the various known departures, from the primitive dicotyledonous type, exhibited by the seedlings of bulbous plants. A change of function accompanied by a necessary change of structure of the ordinary parts of a dicotyledonous seedling has occurred, without any suppression or non-development of the normal structures, and without the precocious development of plumular organs (cf. Text-figs. I-9, p. 420).

In this connexion, also, these Peperomias are of particular interest, for some species have apparently reached a higher state of development and specialization than others. In $P$. peruviana the leaf-like character of the absorbent organ and the cotyledonary character of the aerial leaf are quite unmistakable (cf. Text-figs. 3 and 4, p. 420), and a somewhat similar condition of affairs is seen in $P$. mexicana and $P$. pedicellata. In $P$. umbilicata, H. B. and K., the absorbent cotyledon appears to be rather less leaf-like, and in $P$. parvifolia it has become specialized as a club-shaped organ, and has lost nearly all trace of its leafy character (cf. Text-figs. 3-6, p. 420).

There are, as is well known, examples of bulbous Dicotyledons in several other natural orders, which show pseudo-monocotyledonous modifications in the mode of germination of their seedings. These modifications have been evolved in various ways ; in some cases, perhaps, by a fusion of the two cotyledons (apparently in some Ranunculaceae), or by the abortion of one of the cotyledons (as in Cyclamen). All such cases are of interest when the question of the origin of Monocotyledons is considered; for it is possible that a study of these aberrant forms may throw some light on the subject. The peculiar mode of germination of these geophilous Peperomias suggests a fresh point of view, and the interesting question is raised as to whether the evolution of the Monocotyledons from dicotyledonous ancestors may not have taken place along somewhat similar lines.

\section{Comparison with Araceae.}

Among monocotyledonous orders, the Araceae are the most nearly related to the Piperaceae ${ }^{1}$; they differ from the more typical Monocotyledons in some rather important points, and, according to Scott and Sargant ${ }^{2}$, the vascular bundle of the cotyledon in Arum and Arisaema does not show any trace of the double structure so common in the Liliaceae. In their external features, moreover, the seedlings of certain species of these two genera are strikingly similar to seedlings of the geophilous Peperomias (vide Fig. 49, P1. XXX, and cf. Text-fig. I, p. 4I8).

\footnotetext{
1 Campbell, Ann. Bot., xiv, xv, and xix.

2 Scott and Sargant, Ann. Bot., v, xii, Fig. I4, P1. XXV.
} 
In the case of the seedlings of Arisaema Dracontium ${ }^{1}$, the so-called first leaf, which pushes its way through the soil with a sharply bent petiole from the base of the cotyledonary sheath, invites comparison with the aerial cotyledon of Peperomia peruviana or P.parvifolia. There is, however, one important difference between them, since the first leaf of the Aroid, together with the plumule and radicle, has been carried out of the seed at
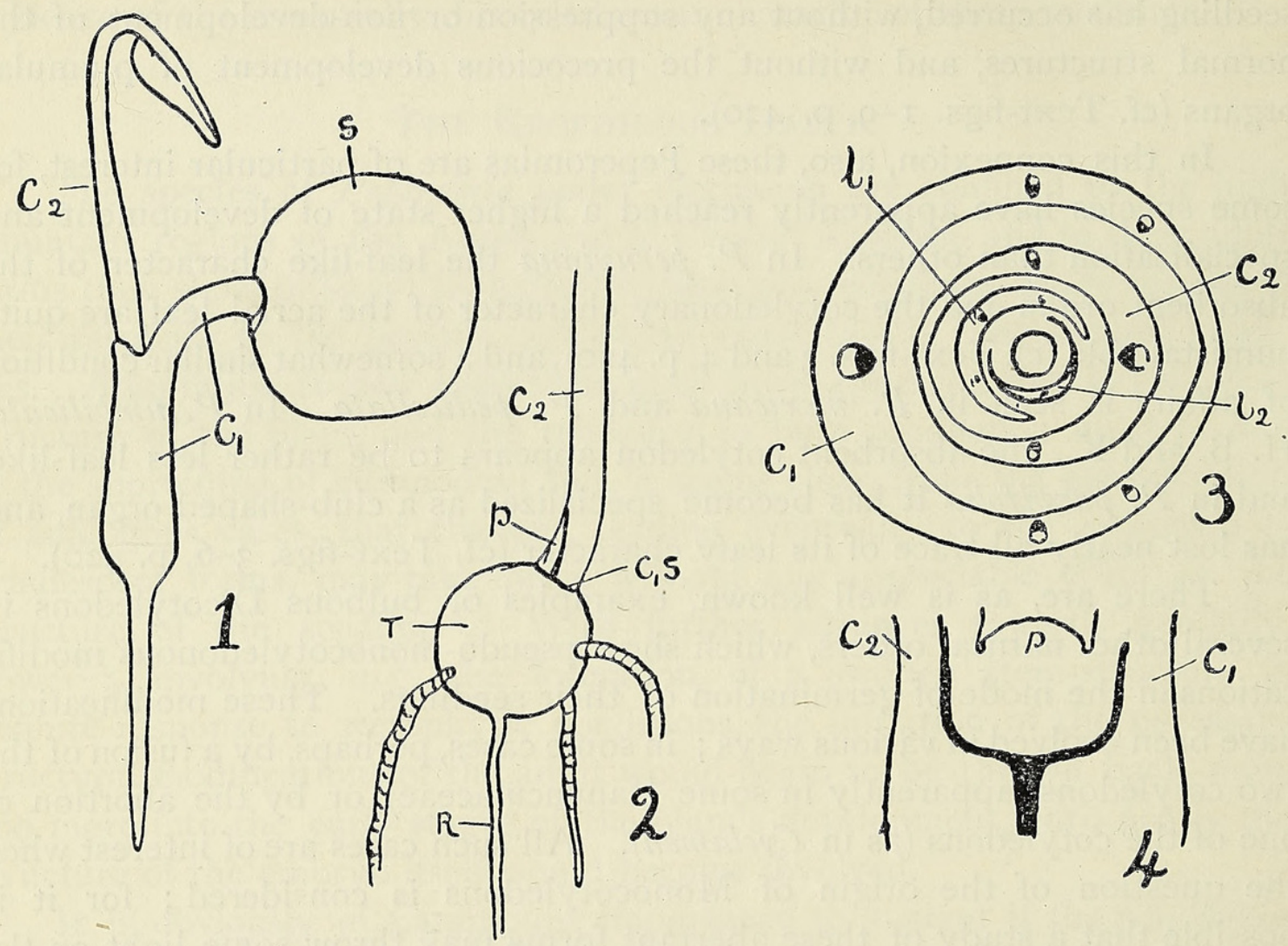

Text-figs. of seedlings of Arisaema and Arum.

$s=$ seed ; $c_{1}=$ absorbent cotyledon; $c_{2}=$ 'first leaf' or aerial cotyledon; $c_{1} s=$ scar of cotyledon $; l_{1}, l_{2}=$ plumular leaves ; $p=$ plumule; $T=$ tuber $; R=$ primary root.

FIGS. I and 2. Arisaema dracontium (after Rimbach).

I. Seedling showing the sheath of the absorbent cotyledon and the upgrowth of the so-called 'first leaf' with its sharply bent petiole.

2. An older stage, with the scar of the absorbent cotyledon. The tuber has developed, and the primary root has been displaced by contractile adventitious roots.

Fig. 3. Arum maculatum (after Scott and Sargant).

3. Diagram representing the course of the bundles in the epicotyledonary region of the stem, the two first seedling leaves $\left(c_{1}, c_{2}\right)$ are seen to be directly opposite to one another.

4. Arum sp., a median longitudinal section through the plumule and hypocotyl, showing the junction of the vascular bundles at the same horizontal level.

an early stage of germination, after the manner of Monocotyledons. This leaf, therefore, grows up from the base of the sheath (cf. Text-fig. 8, p. 420, and Fig. 50, Pl. XXX), and its lamina is not actually withdrawn from the seed, as in $P$. peruviana. The lamina of the 'cotyledon' is represented by the highly specialized rounded or club-shaped absorbent organ (Fig. 49a, Pl. XXX), which always remains in the seed, and resembles the similarly

1 Rimbach, Bot. Gaz., I900, xxx, p. 174, PI. XIII, Figs. I and 2. 
shaped cotyledon in P.parvifolia (Fig. 22, P1. XXIX). A hypocotyledonary bulb is formed in due course, and the structure of the young plant then consists, as in Peperomia, of the primary root, the bulb, and two opposite leaves with an undeveloped plumule (Text-fig. 2, p. 4I 8).

Further it is of interest to notice that a median longitudinal section through the young seedling shows the two leaf-traces, from the 'cotyledon' and from the 'first leaf,' meeting below the plumule at the same horizontal level, and fusing together to form the central cylinder of the bulb and root (Text-fig. 4, p. 4I8).

A transverse section of a young seedling of Arum maculatum, in the neighbourhood of the stem-apex, shows that the midrib of the cotyledon and the midrib of the first leaf are directly opposite to one another, whilst later leaves depart from this arrangement ${ }^{1}$, and have a very different phyllotaxy (Text-fig. 3, p. 4I8).

An analogous case, though still more specialized, seems to be afforded by Tamus communis ${ }^{2}$. The cotyledon has lost almost all trace of its leafy characteristics, but the first leaf, which is the only green leaf of the first year, is rapidly developed, as in Arisaema, and is directly opposite to the absorbent cotyledon. Similar external similarity in the mode of germination is shown by Liliaceae and allied geophilous Monocotyledons. From the foregoing considerations it seems not improbable that the absorbent cotyledon of at least some Monocotyledons is homologous with the modified absorbent cotyledon of these Peperomias, whilst the homologue of their aerial green cotyledon is to be found in the so-called 'first leaf' of the monocotyledonous seedling (Figs. 49 and $5 \circ$, Pl. XXX).

\section{The ORIGiN OF MoNocotyledons.}

In putting forward these views of the possible origin of Monocotyledons from a dicotyledonous ancestry, suggested by the discovery of the seedlings of these geophilous Peperomias, I find myself in opposition to Miss Sargant's well-known theory ${ }^{3}$ of the origin of Monocotyledons from a dicotyledonous stock, deduced from the anatomical study of their seedlings. According to her theory the single cotyledon of Monocotyledons is due to the fusion of the two cotyledons of the ancestral Dicotyledon, whilst in this paper evidence has been brought forward to show that the monocotyledonous habit may have been acquired by the adaptation of the two cotyledons of the ancestral Dicotyledon to different functions.

Very little in the way of anatomical evidence has been adduced to

1 Scott and Sargant, Development of Arum maculatum, Ann. Bot., xii, p. 407, Pl. XXV, Figs. II-I4.

${ }^{2}$ Gardiner and Hill, A. W., Proc. Camb. Phil. Soc., xi, p. 445, Pl. V, Figs. $\left.3-\right\urcorner$.

${ }^{3}$ Sargant, Ann. Bot., vol. xvii, p. I. 


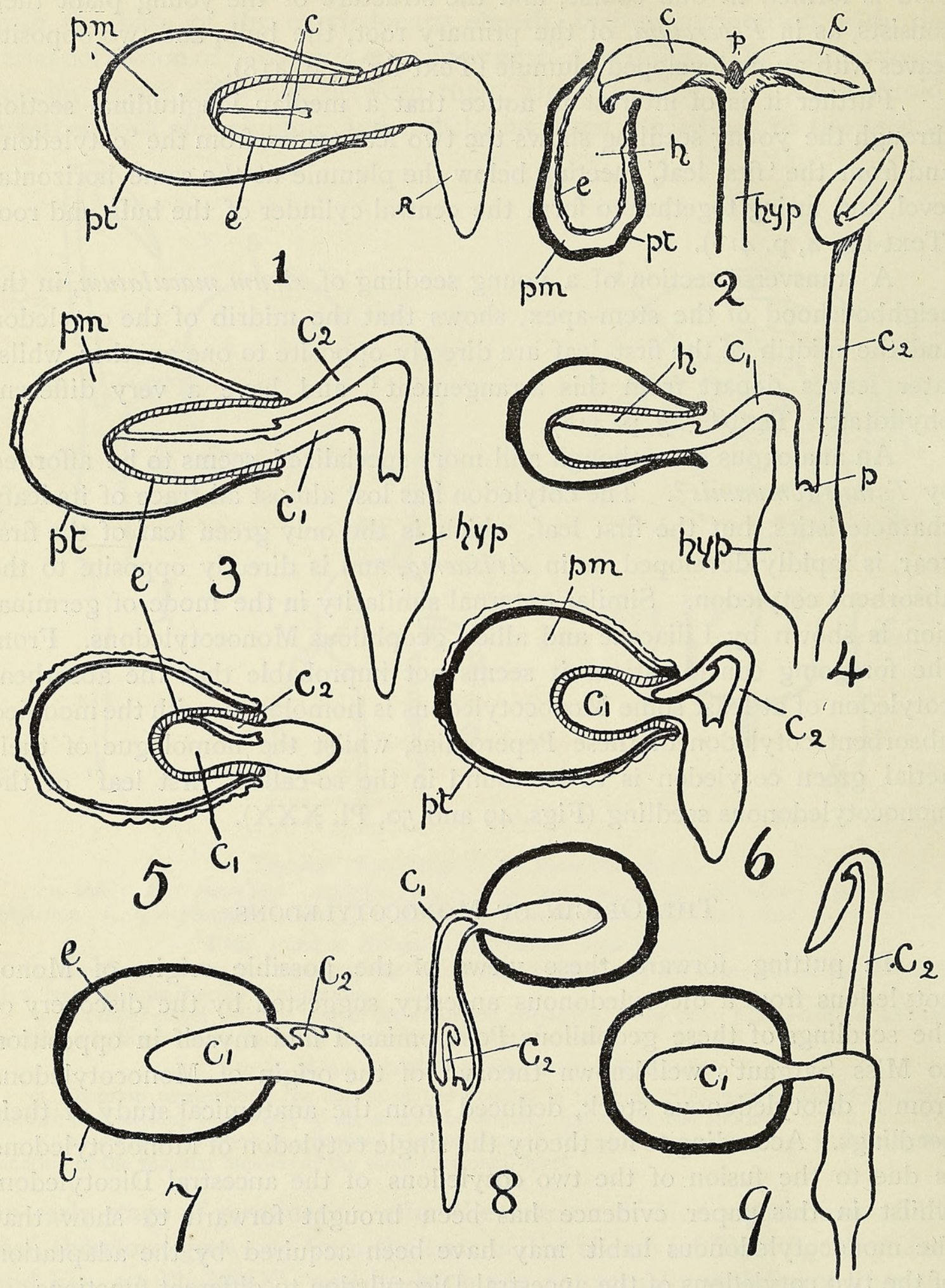

(See opposite page for explanation.) 
Explanation of Text-figures of various seedlings in median longitudinal section.

$p t=$ wall round the seed (pericarp and testa); $t=$ testa $; p m=$ perisperm; $e=$ endosperm; $c=$ cotyledons $; c_{1}=$ absorbent, $c_{2}=$ aerial cotyledon $; p=$ plumule $;$ hy $p=$ hypocotyl $; h=$ cavity in the endosperm left by the withdrawal of one or both cotyledons.

FIGS. I and 2. Peperomia pellucida (after Johnson).

1. Commencement of germination of the dicotyledonous embryo with its sheathing endosperm.

2. The two aerial cotyledons free from the seed, which is empty and shrivelled.

FIGs. 3 and 4 . P. peruviana.

3. Slightly diagrammatic, showing the positions of the two cotyledons within the seed.

4. One cotyledon $\left(c_{1}\right)$ remains within the seed, the other becomes an assimilating organ $\left(c_{2}\right)$; in both cases the laminae are slightly peltate; a large cavity is left in the endosperm on the withdrawal of the aerial cotyledon.

FIGS. 5 and 6. $P$. parvifolia, diagrammatic, since part only of a seedling has been found.

5. The more complete specialization of the absorbent cotyledon $\left(c_{1}\right)$ to form a club-shaped organ (cf. Fig. 22, Pl. XXIX) and the rudimentary aerial cotyledon $\left(c_{2}\right)$.

6. Older seedling, showing the further development of the assimilating cotyledon $\left(c_{2}\right)$, which is of very little value as an absorbent organ, and the commencement of the hypocotyledonary swelling. Only a very small cavity is left in the endosperm on the withdrawal of the aerial cotyledon.

\section{Figs. 7-9, a typical Monocotyledon.}

7. The seed with the young embryo. The 'first leaf' or second cotyledon is very rudimentary, and is covered over by the sheath of the absorbent cotyledon. It is carried out of the seed together with the plumule and radicle.

8. The further development of the rudimentary aerial cotyledon from the base of the sheath of the absorbent organ $\left(c_{1}\right)$.

9. The aerial cotyledon $\left(c_{2}\right)$ has burst through the sheath of the absorbent cotyledon $\left(c_{1}\right)$ and is pushing up into the air with a sharply curved petiole. 
support this view, for it seems open to doubt whether such evidence is, in this case, of very definite phylogenetic value.

The Monocotyledons, at least the bulbous forms and their near allies, are a very highly specialized group of plants which, during a long period of time, have adapted themselves very successfully to xerophytic conditions with the consequent production of considerable morphological changes. It seems only reasonable to suppose that such external changes would be accompanied by corresponding modifications of the internal structure, so that possibly some of the more striking peculiarities of their internal structure may be the outcome of recent adaptations rather than the expression of developmental history.

The adoption of the bulbous habit will, of course, eventually affect the seedling structure, and the amount of modification displayed will no doubt largely depend on the length of time which has elapsed since its initiation, and the degree of perfection which has been attained. The early formation of the underground bulb is apparently essential for the geophilous plant ${ }^{1}$, and for this purpose the absorbent organ, to be efficient, must be able to exert its influence in all directions within the seed (cf. Text-figs. 3-8, p. 420).

To bring about such a state of affairs it is necessary that at the commencement of germination all other embryonic structures shall be removed from the seed as soon as possible; hence we find the assimilating cotyledon-in a rudimentary condition-with the plumule and radicle is carried down into the ground during the first stages of germination (cf. Text-figs. 7 and 8 , p. 420).

These correlated needs, acting over a long period of time, have been the powerful factor in the modification, first of the seedling structure, and finally of the embryo itself. The result of this influence has been to cause the extreme development of one cotyledon to form a pseudo-terminal absorbent organ (Text-fig. 7, p. 420), whilst the other cotyledon-the apparently lateral ' first leaf'-is left to develop from its rudiment outside the seed (cf. Text-figs. 8 and 9, p. 420).

\section{Other Pseudo-Monocotyledonous Dicotyledons.}

In certain other Dicotyledons the geophilous habit has been assumed ${ }^{2}$, and in practically all such cases the seedlings are found to be modified in the direction of the monocotyledonous ideal.

To take the well-known case of Cyclamen, the monocotyledonous condition has been attained by the almost complete suppression of one

${ }^{1}$ e. g. seeds of Crinum cannot be kept for any length of time, but will germinate and produce bulbs and roots in a box without being planted in soil.

${ }^{3}$ A list of such plants is given by Sargant, Ann. Bot., 1. c., p. 76 . 
cotyledon ${ }^{1}$, the single active cotyledon functions first as an absorbent and later as an assimilating organ, and it is only under exceptional cases that the rudiment of the second cotyledon can be induced to develop ${ }^{2}$.

Cyclamen thus appears to have worked out its own special line of evolution to a geophilous condition, which may perhaps be considered as a failure, in so far as such a method does not appear to be capable of very great possibilities ${ }^{3}$ or to have been followed to any extent in other cases.

Another attempt at geophily with its correlated modification of the seedling structure appears to have been made by the Ranunculaceae, where a fusion of the cotyledonary petioles, and perhaps even of their laminae as well, has occurred in some cases ${ }^{4}$, but it does not seem clear that this kind of method has been followed in the past or has led to anything more than modification within this order.

Miss Sargant, of course, contends that the anomalous Ranunculaceae, such as Eranthis with its fused cotyledons, afford the clue to the origin of the monocotyledonous habit of these Monocotyledons. It is certainly true that the internal structure of the cotyledonary tube of Eranthis ${ }^{5}$ shows considerable resemblance to that of the 'single cotyledon' of a form like Annemarhena ${ }^{6}$ which is considered by Miss Sargant to be a primitive type, but it seems an equally possible suggestion that the single median bundle of the monocotyledonous 'single cotyledon' has become divided into two bundles, in correlation in some way with the parallel venation so common to the leaves of Liliaceae, \&c.

${ }^{1}$ Gressner, Bot. Zeit., I874, p. 837. Darwin, Movements of Plants, p. 96 ; cf. Schmid, Bot. Zeit., I902, p. 217. Gressner held the view that the embryo of Cyclamen was dicotyledonous with one cotyledon rudimentary, and this view is confirmed by Schmid, Taf. ix, Fig. 47 , and also by my own work on various species of the genus.

${ }^{2}$ It is interesting to notice that the anatomical character of the petiole of the single cotyledon is suggestive of a double structure.

3 Amongst other psendo-monocotyledonous Dicotyledons, which may perhaps show somewhat similar modifications to Cyclamen, may be mentioned Claytonia Virginica, L.; cf. Holm, Mem. Amer. Acad. Sc., vol. x; Mem. II, p. 30, P1. II, Figs. Io, I I, I3, I4. The 'minute leaf' figured by Holm, apparently opposite to the cotyledon, may represent the undeveloped second cotyledon. Bunium bulbocastanum, L., according to Hegelmaier, Vergl. Untersuch., I878, pp. I39-I40, Pl. VII, Figs. 40, 4I, cf. Schmid, p. 2I6, has a dicotyledonous embryo, and may represent a more reduced condition than Cyclamen. The condition of affairs in Erigenia bulbosa is uncertain, vide Holm, Amer. Journ. Sc., I90I, p. 63 ; seedlings are at present under observation. In Cordydalis cava, Schmid, 1. c., p. 2I 3 , the second cotyledon appears to be entirely aborted.

4 Ramunculus ficaria seems to afford a very good case of fused cotyledons, but a transverse section of the petiole of the 'cotyledon' shows a single entire median bundle. $R$. bulbosus also shows a slight cotyledonary tube, and Dodecatheon (Primulaceae), \&c., also appear to be working on similar lines. In this connexion the frequent tendency to splitting among cotyledons may be referred to. This peculiarity is well seen in seedlings of Acer pseudoplatamus, which often appear to have three or four cotyledons; and the same thing is seen in Primula sinensis, where the apical depression of the cotyledon becomes a deep cut, \&c. In Cyclamen persicum (cult.) the lamina of the single cotyledon is occasionally divided into two distinct laminae.

${ }^{5}$ Sargant, 1. c., p. 52 et seq., Pls. VI, VII, Figs. I-3.

${ }^{6}$ Sargant, Ann. Bot., xiv, p. 633, Pl. XXXIII, Figs. 2, 3 ; New Phytologist, i, I902, p. I07. 
The Relation of the ARoids with other Monocotyledons.

In this connexion it is perhaps worth remarking that the Aroids, e.g. Arum and Arisaema, which appear to be a more primitive and less highly specialized group than the Lilies, do not show the double bundle in the cotyledon. In Anthurium Bakerianum, however, there is an indication of a double bundle ${ }^{1}$, and Miss Sargant concludes that this genus is more primitive than either Arum or Arisaema, and that it occupies an intermediate position between these genera and the Liliaceae, since it shows certain resemblances to a type like that of Zygadenus ${ }^{2}$.

Miss Sargant's phylogenetic sequence ${ }^{3}$ thus commences with a form like Annemarhena, and passing through Zygadenus and Anthurium terminates with the most modified forms, such as Arum and Arisaema.

A point of some interest is suggested by the fact that Anthurium Bakerianum shows more xerophytic characters than Arum or Arisaema, having narrow thick leaves with two lateral veins running parallel to the midrib. Thus this species may perhaps represent a more highly specialized type in the order, and in consequence shows greater modification of its seedling structures ${ }^{4}$.

From this point of view Arum and Arisaema must be considered as simple forms allied to the Piperaceae and not very far removed from their dicotyledonous ancestors; Anthurium, however, owing to its more pronounced xerophily, shows an analogy in its seedlings to the more ancient group of the Lilies whose simplest and least modified forms show a more or less simple, single bundle in the cotyledon (e. g. Zygadenus) ${ }^{5}$, and whose most ancient forms possess the characteristic double bundle which is seen most distinctly in Annemarhena.

\section{SUMMARY.}

In conclusion some of the suggestions brought forward in the latter part of this paper may be summarized. The Ranunculaceae and other dicotyledonous natural orders show various modifications in the structure of the seedlings of some of their genera in the way of cotyledonary tubes, or in the suppression of one of their cotyledons, \&c. They do not appear, however, in these examples to afford any true homology with the seedlings of Monocotyledons or to indicate the mode of origin and method of development of the monocotyledonous habit.

There can be no doubt that the study of the internal structure of the seedlings of Monocotyledons is of great value in throwing light on the

${ }^{1}$ Sargant, 1. c., p. 45 .

${ }^{2}$ Sargant, 1. c., p. 32 .

3 Sargant, 1. c., p. 46.

4 Cf. Campbell, Ann. Bot., xiv, p. 2 I, on the primitive character of Anthurium.

5 Zygadenus has a diarch root; cf. Sargant, 1. c., p. 91, Pl. V, Fig. I2. 
relationships of the various genera to one another, and possibly also of the different Natural orders; but it seems unlikely that such a study will reveal the phylogeny of the whole group, owing to its highly specialized character and the xerophytic modifications which have occurred.

The affinities between two such simple orders as the Piperaceae and Araceae appear to be much more close and definite than between the anomalous Ranunculaceae and the highly specialized Liliaceae, and in the former case the modified pseudo-monocotyledonous Peperomias show definite homologies in their adult condition with the Monocotyledons.

The geophilous Peperomias then may represent a recent attempt, by a fairly simple and possibly primitive group of Dicotyledons, to attain to the geophilous condition reached by Monocotyledons.

This attempt must be regarded as a perfectly independent development, which has happened to have worked along lines similar to those which in times past gave rise to the existing class of Monocotyledons from a dicotyledonous ancestry.

\section{EXPLANATION OF FIGURES IN PLATES.}

\section{Illustrating Mr. A. W. Hill's paper on Peperomia.}

Figures $1-29$ have been drawn from my own material preserved in spirit, and Figs. $30-47$ from herbarium material. Figs. I, 2, I8, 24-26, 28, 29 to $3 \mathrm{I}$ are from photographs. The rest are from my own drawings. The natural size of the specimens is indicated alongside each figure in most cases.

\section{PLATE XXIX.}

Figures I-I7. Peperomia periviana, Dahlst.

Fig. I. A fully developed bulbous plant, showing the bulb $(\mathrm{cm})$ with the roots springing from the sides, the peltate orbicular leaves and the inflorescences $(s)$. Nat. size. A. W. Hill, no. 180, in Herb. Kew.

Fig. 2. An older specimen with a large and irregular corm and much longer petioles and inflorescences. Nat. size.

Fig. 3. A fruit in median longitudinal section, showing style and stigma $(s)$; the pericarp $(\not p)$, with its gland-cells $(g)$, the testa $(t)$, perisperm $(p m)$, and the outline of the endosperm $(e)$. Mag. $\times 64$.

Fig. 4. A small piece of the outer layers of the pericarp, showing the slight pit with a single gland-cell. Mag. $\times 300$.

Fig. 5. Very young seedling, both cotyledons are enclosed in the seed and there is a slight hypocotyledonary swelling. The petiole of the aerial cotyledon $\left(\begin{array}{ll}c & 2\end{array}\right)$ is the more sharply bent.

Fig. 6. Slightly older seedling, the aerial cotyledon has been withdrawn from the seed; cf. Text-fig. 3, p. 402 .

Fig. 7. The petiole has straightened and the peltate lamina has expanded, the absorbent cotyledon $\left(c_{1}\right)$ remains within the seed.

Fig. 8. A seedling of about the same age as Fig. 7 ; the seed has been dissected off and the seedling placed in glycerine. The lamina of the aerial cotyledon shows three veins, whilst that of the slightly peltate absorbent cotyledon has only a single median vein. The fusion of the two cotyledonary traces below the plumule can also be seen. 
Fig. 9. A young bulb or corm at the end of the first vegetative period, showing the remains of the primary root $(r)$, the remains of the absorbent and the scar of the aerial cotyledon.

Fig. 10. A young plant during the second vegetative period, the corm $(\mathrm{cm})$ is covered by hairs. The absorbent cotyledon with the seed and the remnant of the aerial cotyledon are seen. The first leaf $\left(l_{1}\right)$ has developed.

Fig. I I. A similar plant, a branched adventitious root has developed from the corm.

Fig. I2. An older plant with the third leaf developed.

Fig. I3. A young seedling, showing the relation of the two cotyledons within the seed; cf. Text-figs. 3 and 4 , p. 420 .

Fig. I 4. Median longitudinal section through the petioles of the cotyledon and the hypocotyl $(h y p$.$) ; the junction of the two bundles below the plumule ( p l$.) is well seen. Mag. $\times 300$.

Fig. I 5. An older plant, two green plumular leaves and several adventitious roots have developed from the tuber.

Fig. I6. Transverse section of a germinating seed about the age of Fig. 6 ; the remains of the pericarp and testa $(p t$.) surround the perisperm $(p m$.$) . This is bounded internally by the endosperm-$ represented by a darkly stained band-and within the cavity of the endosperm lies the lamina of the absorbent cotyledon $\left(c_{1}\right.$.), its dorsi-ventral structure is still preserved and the midrib is indicated. Mag. $\times$ I 20.

Fig. I7. Transverse section of the primary root at the base of the hypocotyl of a seedling similar to Fig. 7. The small diarch xylem plate consists of about two lignified elements $(x$.). $e n=$ endodermis ; ph. $=$ phloem. Mag. $\times 300$.

Figs. 18-28. P. parvifolia, C. DC.

Fig. I8. A fruit in a slightly oblique median longitudinal section, showing the short style $(s)$ with the micropyle $(m)$ pits in the outer layer of the pericarp with groups of gland-cells $(g)$ at their bases; $(p m$.$) perisperm; (e.) endosperm. Mag. \times 64$.

Fig. 19. A pit with its group of four gland-cells in a section parallel to the surface of the fruit. Mag. $\times 300$.

Fig. 20. Two pits in longitudinal section, showing the gland-cells, with some of their contents stained by eosin. Mag. $\times 300$.

Fig. 2I. A germinated seed with the petiole of the absorbent cotyledon $\left(c_{1}\right)$, the rest of the seedling has been lost.

Fig. 22. The absorbent cotyledon with its petiole and club-shaped lamina ( $\left.l_{0}\right)$, the seed-coats, \&c. seen in Fig. 2 I have been dissected away; cf. Text-figs. 5 and 6, p. 420.

Fig. 23. A young plant with the remnants of the two cotyledons $\left(c_{1}, c_{2}\right)$, the first leaf has developed, and there is a basal tuft of roots.

Fig. 24. An older bulb with several leaf-scars and two leaves. About nat. size.

Fig. 25. A slightly older stage with well developed roots.

Fig. 26. A young bulb with an inflorescence (s.).

Fig. 27. A well developed plant, the corm $(\mathrm{cm}$. $)$ bears a terminal crown of leaves and inflorescences (s.) and a large basal tuft of roots. Nat. size. A. W. Hill, No. I8I in Herb. Kew.

Fig. 28. An old corm. About nat. size.

Fig. 29. $P$. verruculosa, Dahlst. The fruit in median longitudinal section to compare with that of $P$. parvifolia; the pericarp is very deeply pitted, and the innermost layer consists of large cells; the wall of the testa is thick. Lettering as in Fig. 3. Mag. $\times 64$. A. W. Hill, No. I82, Herb. Kew.

Fig. 30. P. umbilicata, H. B. and K., a seedling with the seed in section; the absorbent cotyledon $\left(c_{1}\right)$ is more or less club-shaped and surrounded by the endosperm (e.). Mexico, No. 63I, Bourgeau, in Herb. Kew. Cf. Fig. $2 \mathrm{I}$ and Text-figs. 5 and 6, p. 420.

\section{PLATE XXX.}

Fig. 31. P. umbilicata, H. B. and K. A fruit in median longitudinal section, the small pits have only a single gland-cell at their base. The narrow pericarp and almost circular seed should be noted; cf. with P. parvifolia. Mag. $\times 64$. Mexico, No. 802, Parry and Palmer, in Herb. Kew. 
Figs. 32-41. P. pedicellata, Dahlst.

Fig. 32. A complete plant, showing the spherical tuber $(\mathrm{cm}$.) with the roots springing from the upper surface, the leaves and long inflorescences (s.). Nat. size. No. 3829 , J. Donnell Smith, in Herb. Kew.

Fig. 33. A young seedling, showing the pedicellate fruit $\left(f_{.}\right)$and the petiole of the absorbent cotyledon $\left(c_{1}\right)$, the aerial cotyledon $\left(c_{2}\right)$ with its somewhat oblique primary root $\left(r_{0}\right)$, and the apogeotropic lateral root $\left(r_{1}\right)$ which has become horizontal.

Fig. 34. A slightly younger seedling than Fig. 33, with the seed dissected away, showing the leaf-lamina of the absorbent cotyledon, the median primary root and the ascending lateral root.

Fig. 35. An older seedling, the lamina of the absorbent cotyledon is well seen; the primary root is slightly displaced to one side, and two secondary roots have developed $\left(r_{1}, r_{2}\right)$.

Fig. 36. An older seedling, showing the development of the first leaf $\left(l_{1}\right)$ and the lateral position of the roots.

Fig. 37. A young seedling, showing the petioles of the two cotyledons and the root-scar $(r$.$) to$ one side of the plumule on the upper surface of the tuber.

Fig. $3^{8}$. An older tuber seen from above, showing the scars of the two cotyledons, the first leaf and the apical tuft of roots $\left(R_{\bullet}\right)$.

Fig. 39. A fully developed plant seen from the side, the absorbent cotyledon and fruit $\left(f_{\text {. }}\right)$ are still retained.

Fig. 40. A tuber like that of Fig. 39, in longitudinal section through the points of origin of stem $(p$.$) and roots (R$.$) ; note the curved stele (s t$.$) between these two foints. This tuber was$ $1.2 \mathrm{~mm}$. long by $1.8 \mathrm{~mm}$. in breadth.

Fig. 4I. Fruit in median longitudinal section showing the long style; the pericarp is like that of $P$. peruviana. Mag. $\times 64$.

\section{Figs. 42-45. P. mexicana, Miq.}

Fig. 42. A complete plant with short tuberous rhizome $(R h$.$) , scarcely peltate leaves and$ inflorescences. Nat. size. Mexico, No. 7, I I I, Galleoti, in Herb. Kew.

Fig. 43. A fruit showing the long style and peltate stigma (st.).

Fig. 44. A young seedling with the seed dissected away, showing the two cotyledons, the swollen hypocotyl, the primary root, and a horizontal lateral root.

Fig. 45. A similar seedling showing the leaf-like lamina of the absorbent cotyledon, the swollen hypocotyl, \&c.

\section{Figs. 46-49. P. macrandra, C. DC.}

Fig. 46. A piece of a well developed plant with a tuberous creeping rhizome (Rh.), showing leaf-scars $(l s$.$) , and branch-scars (bs.), and adventitious roots; also the large glabrous peltate leaves$ and an inflorescence. Nat. size. Mexico, No. 4654, Pringle, in Herb. Brit. Mus. The specimens in Herb. Kew are much larger with longer leaf-petioles and long inflorescences.

Fig. 47. A flower with the bract $(b$.$) and a young carpel.$

Fig. 48. A young seedling, the aerial cotyledon has a large thin lamina.

Figs. 49-50. Arum, sp.

Fig. 49. A young seedling with its seed (s.). The ' first leaf' $\left(c_{2}\right)$ has emerged from the sheath of the absorbent cotyledon $\left(c_{1}\right)$. Nat. size.

Fig. $49 a$. The tip or modified lamina (l.) of the absorbent cotyledon seen in Fig. 48 ; cf. Fig. 22, Pl. XXIX.

Fig. 50. The lamina of the 'first leaf'--the modified second cotyledon-of an older seedling. About nat. size. 
Annals of Botany.
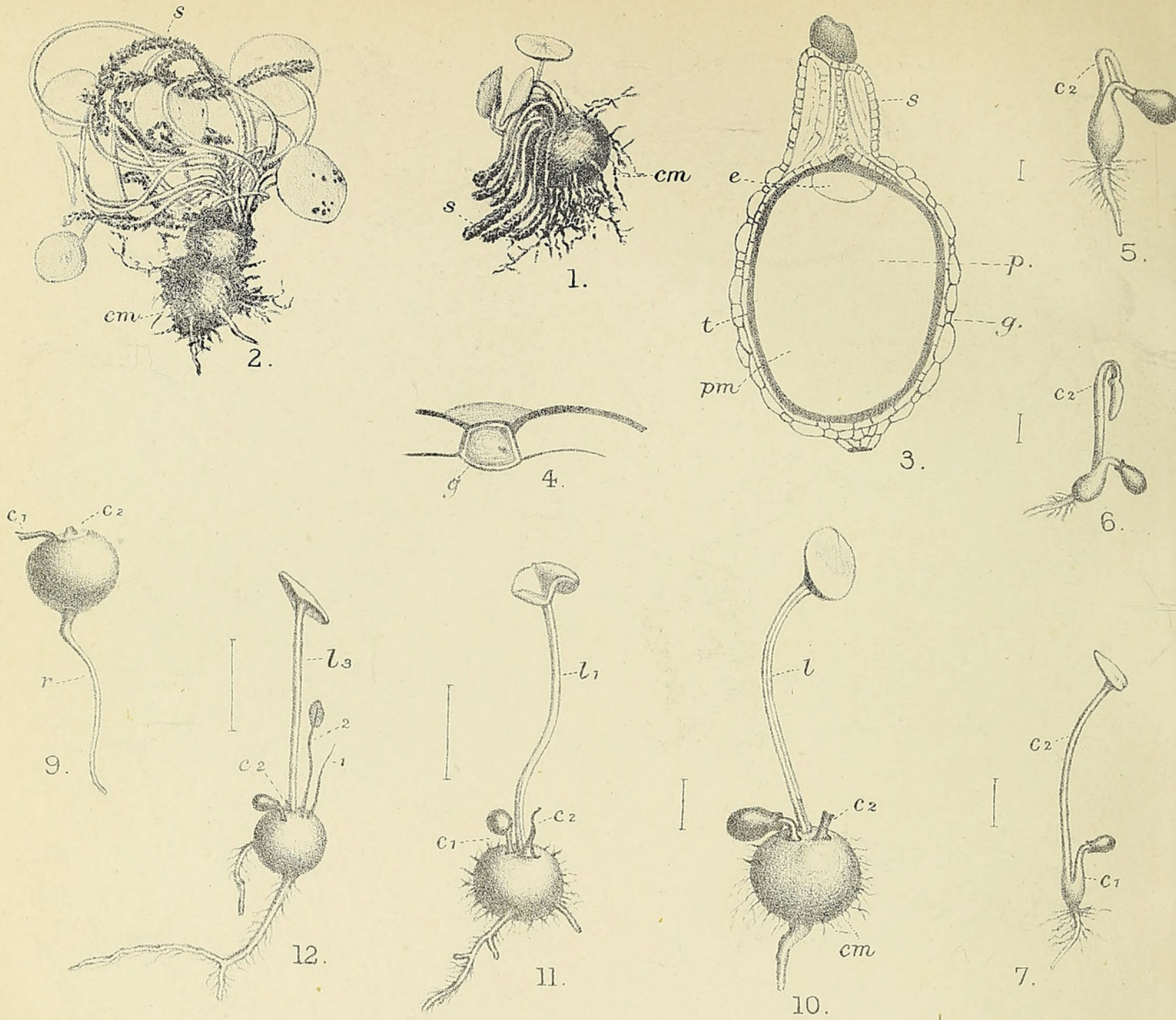

6.

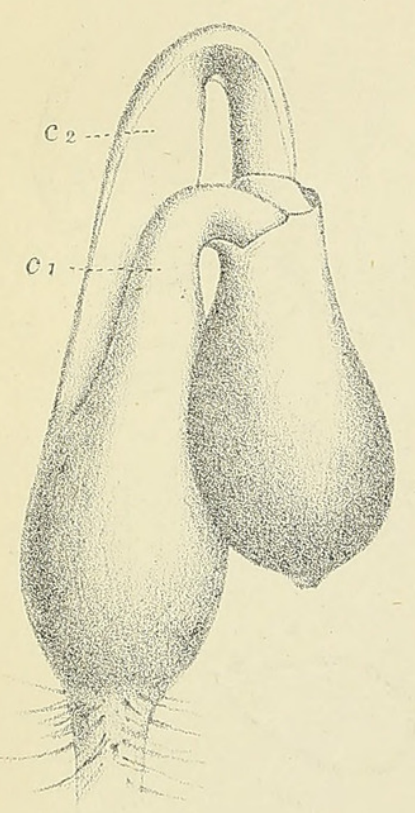

13
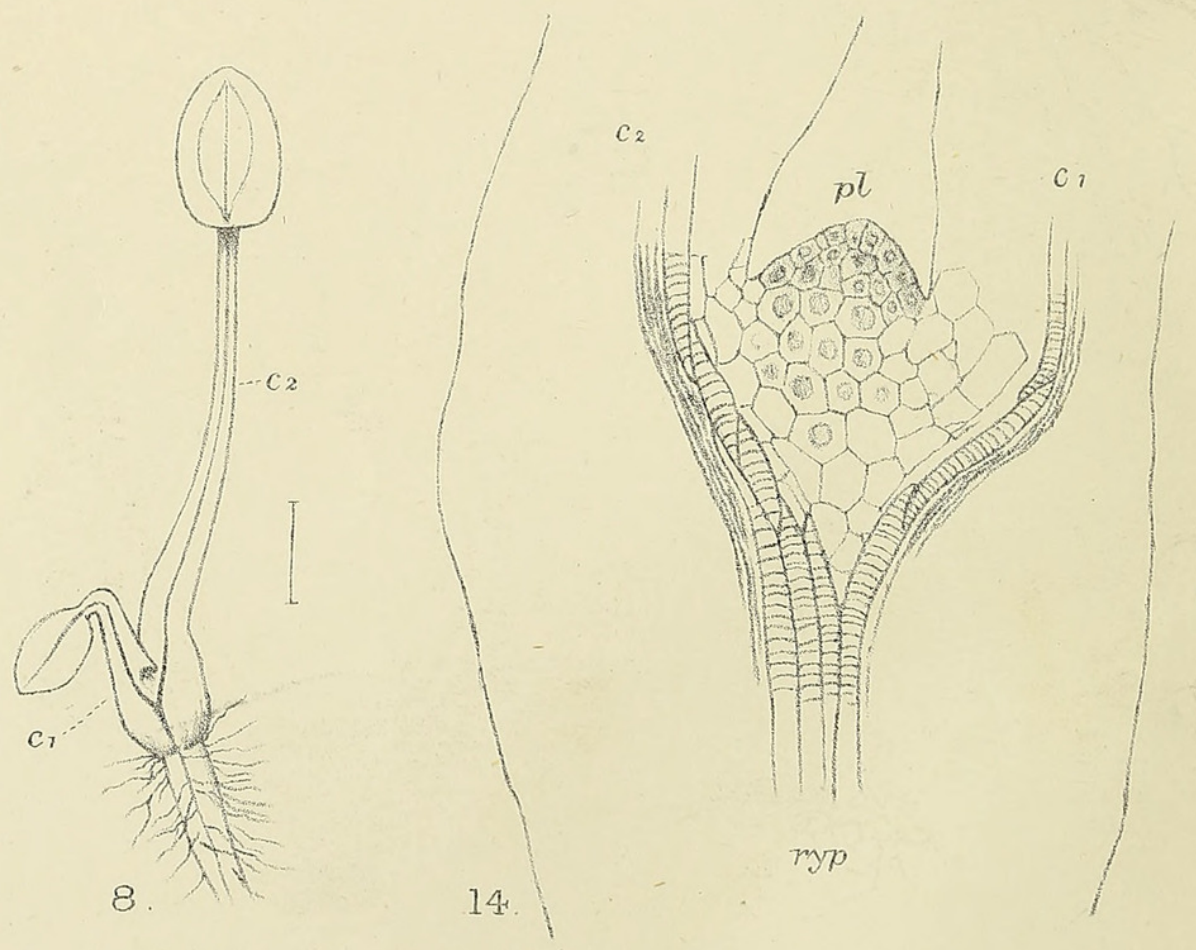

A.W.H. del 
Vol XX, PLXXIX.

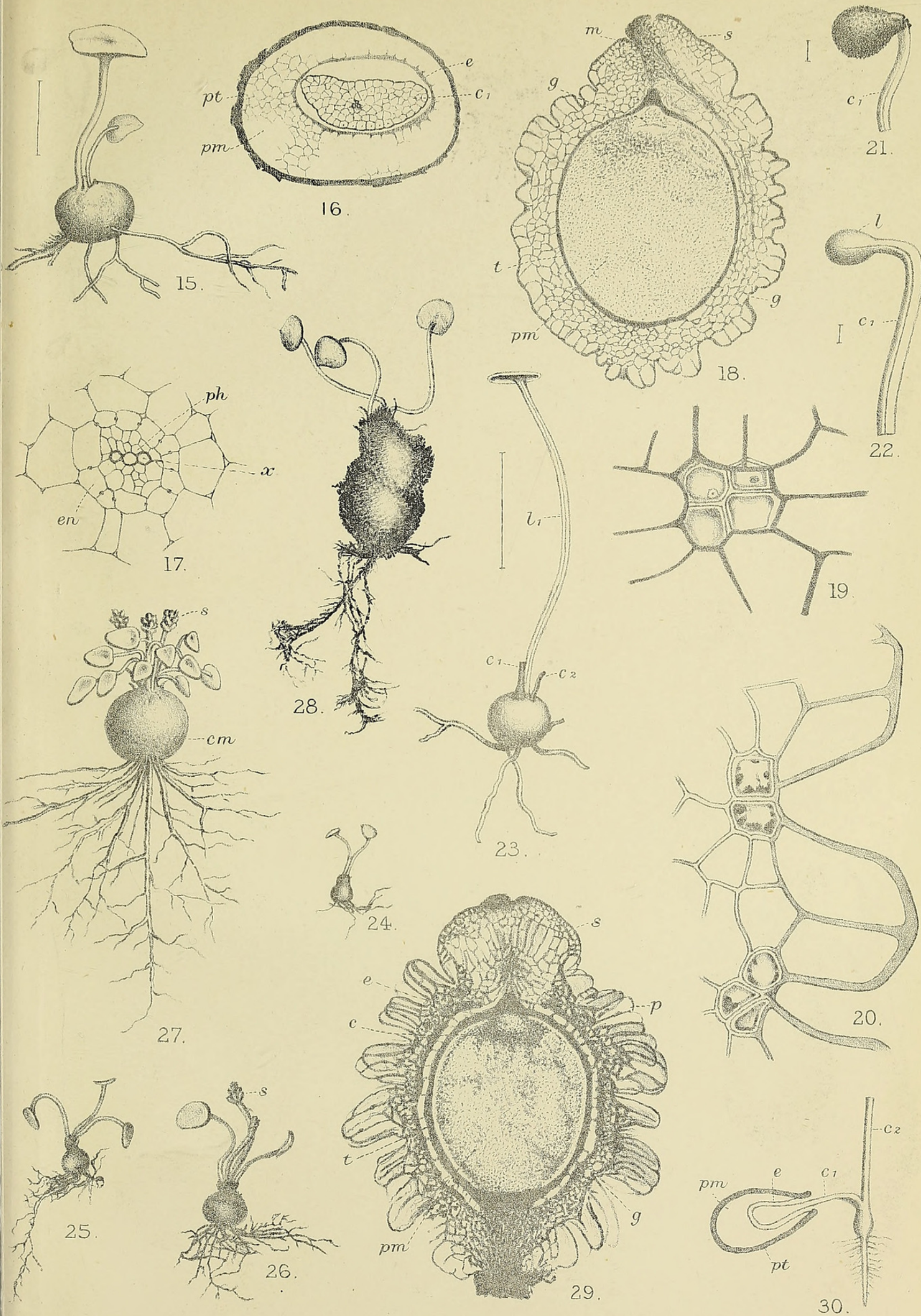


Annals of Botany.
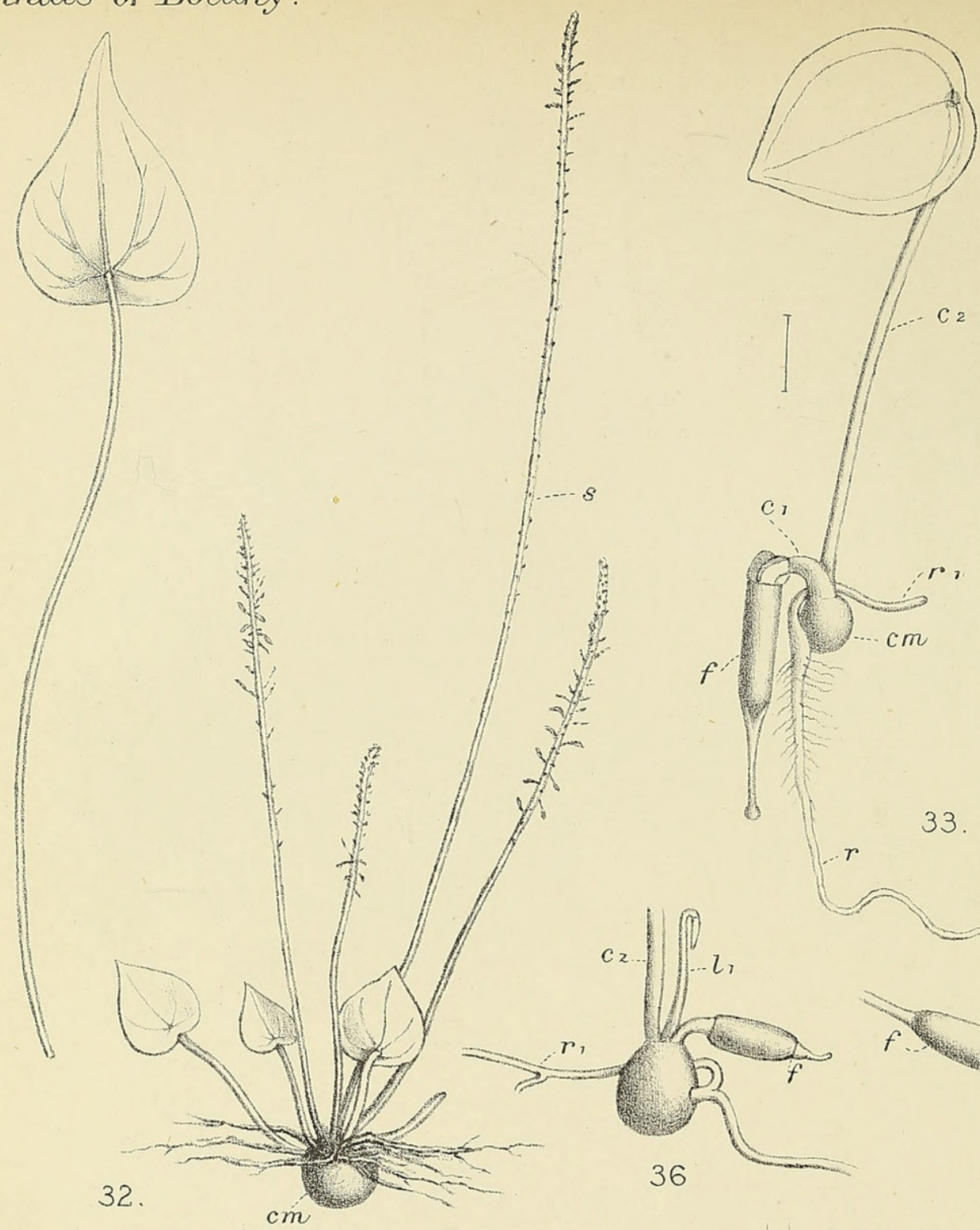


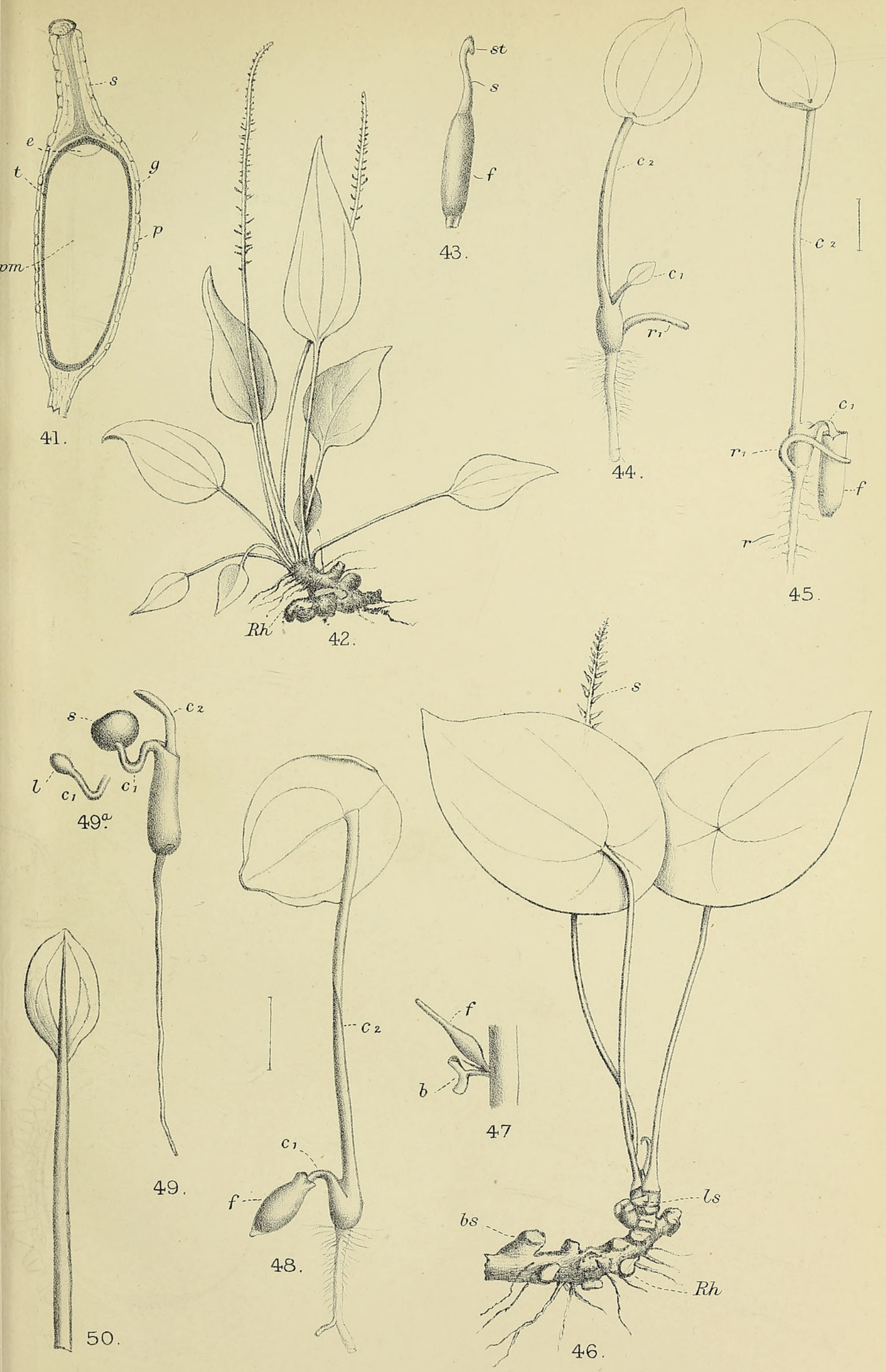



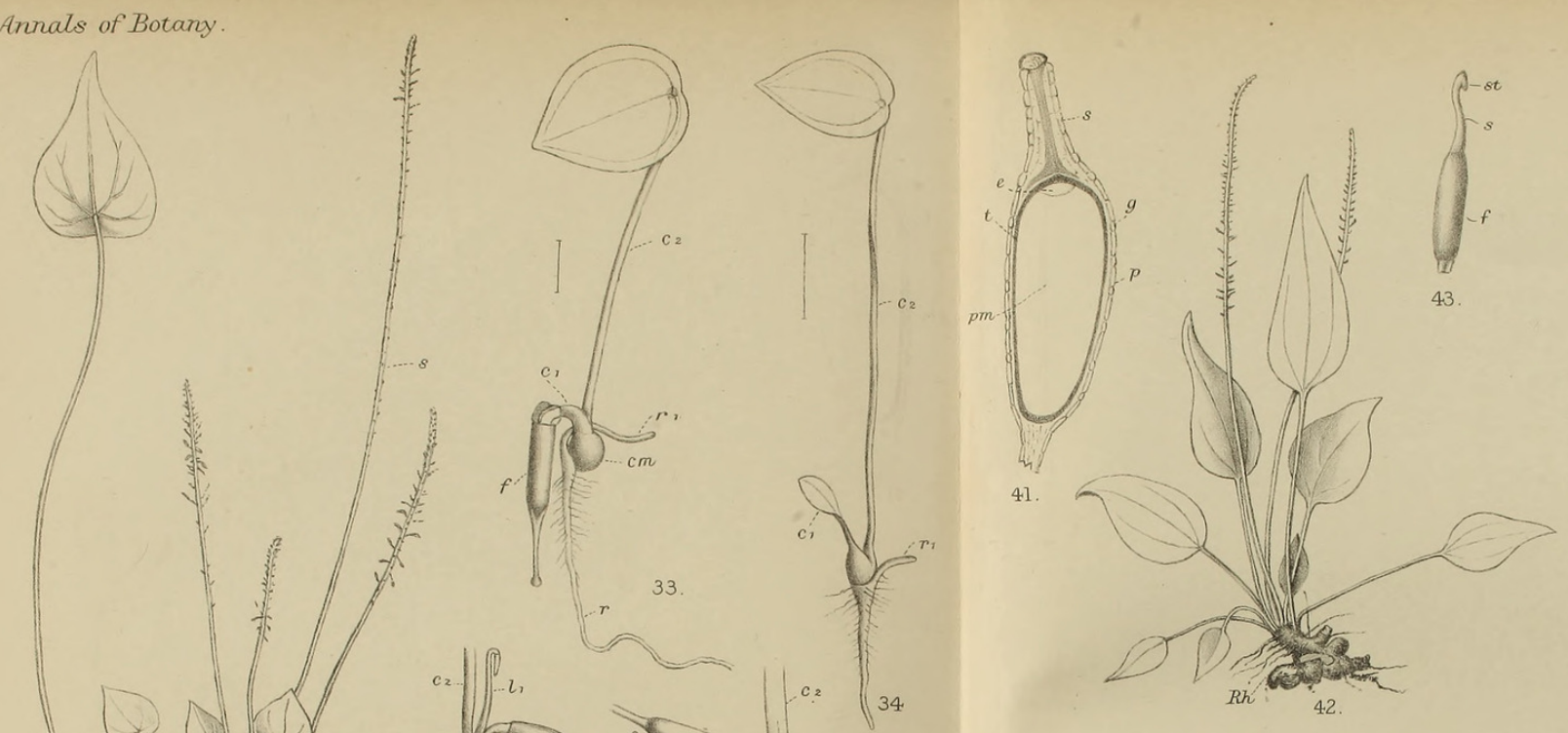

Vol XX, Pl XXX.

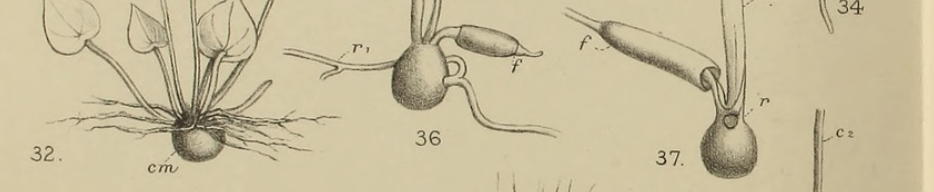

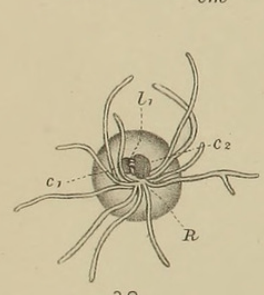
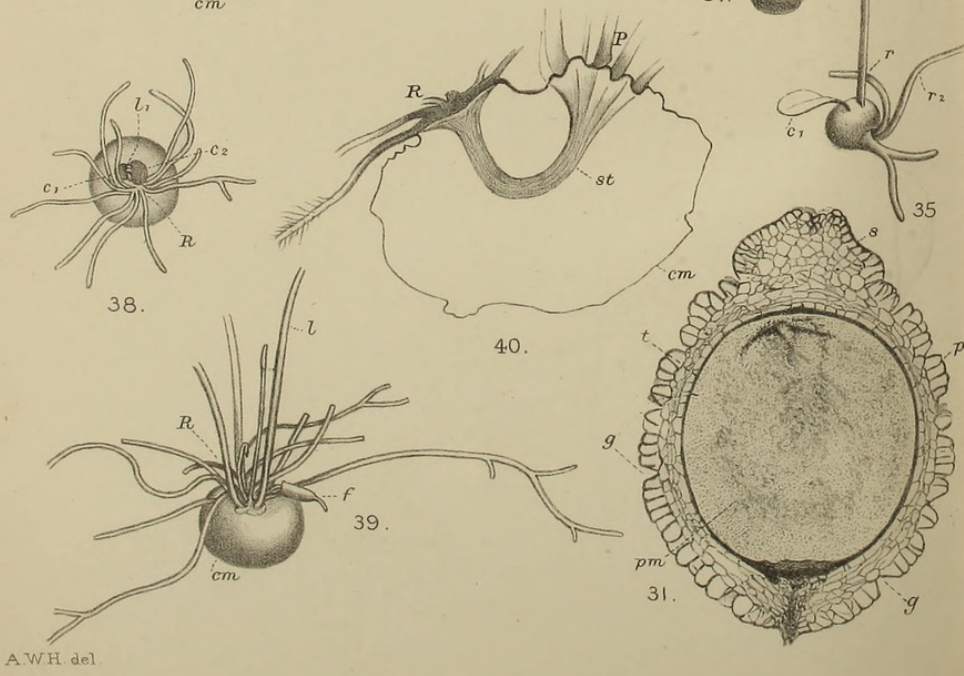

HILL - SEEDLINGS OF PEPEROMIA.

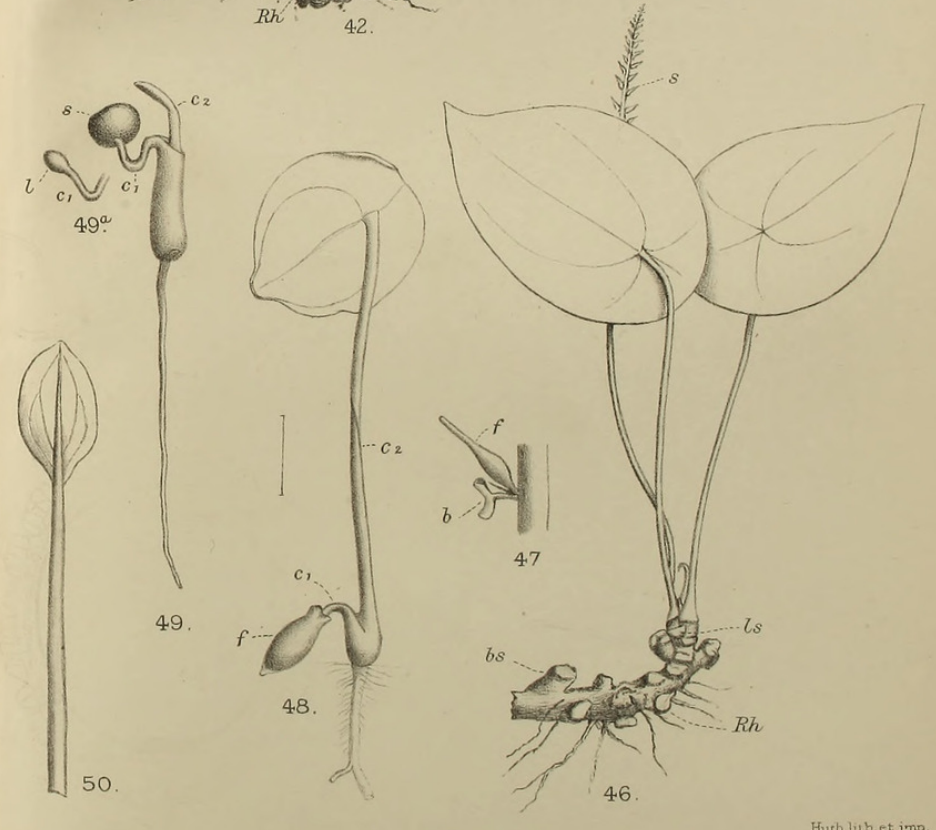




\section{$2 \mathrm{BHL}$ Biodiversity Heritage Library}

Hill, Arthur William. 1906. "The morphology and seedling structure of the geophilous species of Peperomia, together with some views on the origin of monocotyledons." Annals of botany 20, 395-427. https://doi.org/10.1093/oxfordjournals.aob.a089110.

View This Item Online: https://www.biodiversitylibrary.org/item/234848

DOI: https://doi.org/10.1093/oxfordjournals.aob.a089110

Permalink: https://www.biodiversitylibrary.org/partpdf/318850

\section{Holding Institution}

Smithsonian Libraries

\section{Sponsored by}

Biodiversity Heritage Library

\section{Copyright \& Reuse}

Copyright Status: Not in copyright. The BHL knows of no copyright restrictions on this item.

This document was created from content at the Biodiversity Heritage Library, the world's largest open access digital library for biodiversity literature and archives. Visit BHL at https://www.biodiversitylibrary.org. 